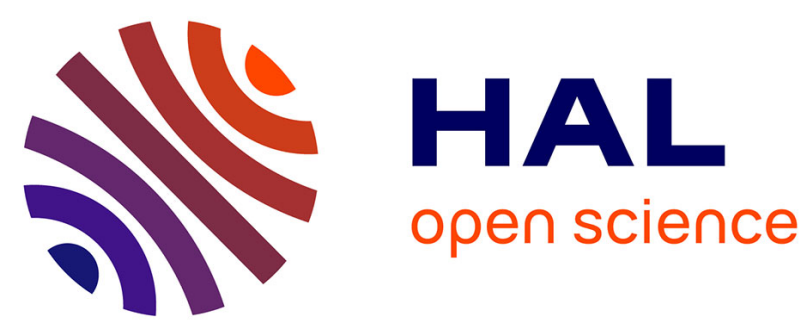

\title{
Reorganization of a photosensitive carbo-benzene layer in a triptych nanocatalyst with enhancement of the photocatalytic hydrogen production from water
} Hala Assi, Kévin Cocq, Jérémy Cure, Gérald Casterou, Kévin Castello Lux, Vincent Collière, Laure Vendier, Pierre Fau, Valérie Maraval, Katia Fajerwerg, et al.

\section{To cite this version:}

Hala Assi, Kévin Cocq, Jérémy Cure, Gérald Casterou, Kévin Castello Lux, et al.. Reorganization of a photosensitive carbo-benzene layer in a triptych nanocatalyst with enhancement of the photocatalytic hydrogen production from water. International Journal of Hydrogen Energy, 2020, 45 (46), pp.2476524778. 10.1016/j.ijhydene.2020.06.255 . hal-02947701

\section{HAL Id: hal-02947701 \\ https://hal.science/hal-02947701}

Submitted on 24 Nov 2020

HAL is a multi-disciplinary open access archive for the deposit and dissemination of scientific research documents, whether they are published or not. The documents may come from teaching and research institutions in France or abroad, or from public or private research centers.
L'archive ouverte pluridisciplinaire $\mathbf{H A L}$, est destinée au dépôt et à la diffusion de documents scientifiques de niveau recherche, publiés ou non, émanant des établissements d'enseignement et de recherche français ou étrangers, des laboratoires publics ou privés. 


\title{
Reorganization of a photosensitive carbo-benzene layer in a triptych nanocatalyst with enhancement of the photocatalytic hydrogen production from water
}

Hala Assi ${ }^{1}$, Kévin Cocq ${ }^{1, *}$, Jérémy Cure ${ }^{1,2, *}$, Gérald Casterou $^{l, *}$, Kévin Castello Lux ${ }^{l}$, Vincent Collière $^{l}$, Laure Vendier ${ }^{l}$, Pierre Fau ${ }^{1}$, Valérie Maraval ${ }^{1}$, Katia Fajerwerg $^{l}$, Yves J. Chabal ${ }^{2}$, Remi Chauvin ${ }^{1}$, Myrtil L. Kahn ${ }^{1}$

${ }^{1}$ LCC-CNRS, University of Toulouse, 205 route de Narbonne, 31077 Toulouse, France

${ }^{2}$ Department of Materials Science and Engineering, University of Texas at Dallas, Richardson, TX (USA)

Keywords: reorganization; carbo-benzene dye; silver nanoparticles; titanium dioxide nanoparticles; triptych material; photocatalytic hydrogen production

\begin{abstract}
:
The preparation of a triptych nanomaterial made of $\mathrm{TiO}_{2}$ nanoparticles as semiconductor, Ag plasmonic nanoparticles and a carbo-benzene macrocyclic molecule as photosensitizer is described, and used to produce hydrogen by photo-reduction of pure deionized water under 2.2
\end{abstract}


bar argon pressure without any electrical input. Silver nanoparticles $(\sim 5 \mathrm{~nm})$ are grafted onto the surface of commercial $\mathrm{TiO}_{2}$ nanoparticles $(\sim 23 \mathrm{~nm})$ by a photo-deposition process using an original silver amidinate precursor. The thickness of the photosensitive layer $(2 \mathrm{~nm})$, which completes the assembly, plays a crucial role in the efficiency and robustness of the triptych nanocatalyst. Thanks to the organic layer reorganization during the first $\sim 24 \mathrm{~h}$ of irradiation, it leads to an enhancement of the hydrogen production rate up to 5 times. The amount of silver and carbo-benzene are optimized, along with the mass concentration of nanocatalyst in water and the $\mathrm{pH}$ of the aqueous medium, to allow reaching a hydrogen production rate of 22.1 $\mu \mathrm{mol} \cdot \mathrm{h}^{-1} \cdot \mathrm{g}_{\text {photocatalyst }}{ }^{-1}$.

\section{Introduction}

Production of sustainable and green sources of energy is one of the most important challenges of the $\mathrm{XXI}^{\text {th }}$ century and is now urgent because of the global warming and its consequences. To address this challenge, hydrogen $\left(\mathrm{H}_{2}\right)$ appears to be an unavoidable candidate, thanks to its powerful energetic profile [1-3]. World production of hydrogen is today based for ca $96 \%$ on fossil fuels, because of cheap industrial processes and materials. The remaining $4 \%$ mainly correspond to electrolysis of water (i.e. splitting of water molecules into hydrogen and oxygen with an electric current), but it requires the use of a renewable source of electricity to be considered as a green method. Since Honda and Fujishima have demonstrated, in 1972 , that a pure photocatalytic process can be used to produce hydrogen from water (i.e. without applying an external potential) [4], using titanium dioxide $\left(\mathrm{TiO}_{2}\right)$ as semi-conductor (SC) under UV irradiation, several improvements of this initial method were reported. The modification of the $\mathrm{TiO}_{2}$ crystalline phase [5, 6], shape [7], size [8] were investigated, and its coupling with noble metal plasmonic nanoparticles (NPs) such as Au [9-14], Ag [15-17], Pt 
[18-22], or a combination of NPs was considered [23-25]. In order to harvest a larger part of the solar light, the use of molecular and biomolecular dyes as photosensitizer (PS) was proposed [26-29], and more recently, the combination of plasmonic Au or Ag NPs with carbon-based materials such as carbon nanotubes (CNTs) [30], graphene from reduced graphene oxide (rGO) [31-35], porphyrin [36] or graphitic carbon nitride $\left(\mathrm{g}-\mathrm{C}_{3} \mathrm{~N}_{4}\right)$ [37-42].

One of the challenges in the design of triptych photocatalysts (i.e. the combination of a SC, plasmonic NPs and a PS layer) still concerns the optimal integration of a PS to benefit from its physical and chemical properties. In a recent report [43], a $\mathrm{TiO}_{2} / \mathrm{Ag} / \mathrm{Cbz}$ triptych thin film photocatalyst (with $\mathrm{TiO}_{2}$ as $\mathrm{SC}, \mathrm{Ag}$ as plasmonic NPs and carbo-benzene (Cbz) as PS) was shown to exhibit a remarkable efficiency for hydrogen production by a pure photocatalytic process $[44,45]$. The controlled deposition of a Cbz PS layer of optimal thickness onto the $\mathrm{TiO}_{2} / \mathrm{Ag}$ thin film surface was however shown to be of major importance to take advantage of its unique properties such as a large absorbance in the visible region [46] and a high single molecule conductance [47]. In this context, this work focuses on the fine assembling of a novel triptych nanomaterial and the study of the crucial role of the Cbz layer (Figure 1) [43]. The use of $\mathrm{TiO}_{2} \mathrm{P} 25$ Aeroxide $^{\circledR}$ (NPs of $23 \mathrm{~nm}$ mean size with $50 \pm 15 \mathrm{~m}^{2} / \mathrm{g}$ specific surface area) is chosen in order to improve the photo-active specific surface and thus the hydrogen production rate from pure deionized water. The plasmonic NPs are prepared by UV irradiation of a silver amidinate precursor (silver N,N'-diisopropylacetamidinate, hereafter denoted as Ag(amd)) [48] and deposited on the $\mathrm{TiO}_{2}$ surface previously covered with a thin layer of Cbz. The coating of the PS onto the $\mathrm{TiO}_{2}$ surface before photo-deposition of the Ag NPs allows their stabilization along with their size and shape control without requiring any additional organic stabilizing agents [48]. Furthermore, $\operatorname{Ag}(\mathrm{amd})$ is an original precursor for the synthesis of Ag NPs, avoiding the use of alcoholic aqueous solutions $\left(\mathrm{EtOH} / \mathrm{H}_{2} \mathrm{O}\right.$ for example) that are necessary 
with $\mathrm{AgNO}_{3}$ salts [43], and which may alter the PS layer on $\mathrm{TiO}_{2}$ due to its solubilization properties in such solvents.

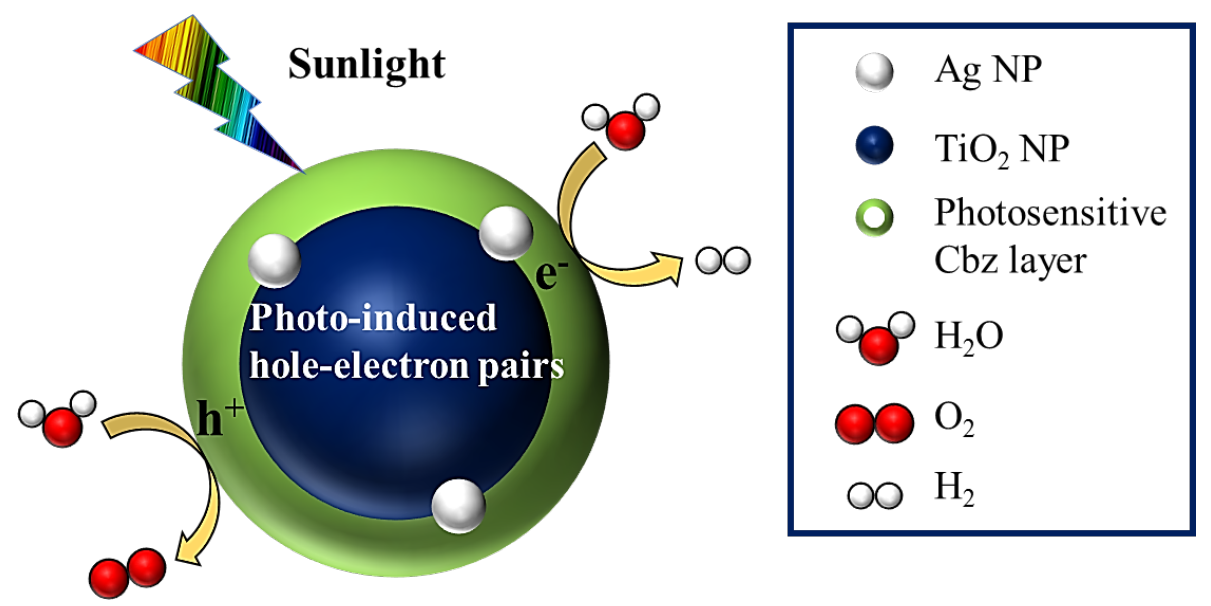

Figure 1. Working principle of the triptych nanocatalyst composed by Aeroxide ${ }^{\circledR} \mathrm{TiO}_{2} \mathrm{NP}$ (blue sphere), Ag NPs (white sphere) and carbo-benzene dye (green crown) for hydrogen production from pure deionized water (for a molecular structure of the carbo-benzene, see Figure 2e).

The quantities of $\mathrm{Cbz}$ and $\mathrm{Ag}$ precursor engaged in the synthesis of the triptych nanocatalyst are crucial, as non-optimal ratios decrease the photocatalytic activity [43], as well as the size distribution of Ag NPs which is related to the initial amount of $\mathrm{Ag}(\mathrm{amd})$ used. In this study we focused first on a triptych nanocatalyst (Figure 1) made of $2 \%$ molar of Cbz (PS) and 3\% molar of $\mathrm{Ag}$ (NPs) with respect to $\mathrm{TiO}_{2}$ (hereafter denoted as $\mathrm{TiO}_{2} / \mathrm{Cbz}^{2 \%} / \mathrm{Ag}^{3 \%}$ ). This triptych system, tested under simulated sunlight in pure deionized water exhibits a long lifetime over $90 \mathrm{~h}$, going through an unprecedented reorganization of the photosensitive Cbz layer (demonstrated by physical and spectroscopic experiments) and leading to an enhancement of the hydrogen production by a factor greater then 5. A complete study of the influence of the Cbz thickness, $\mathrm{Ag}$ content and $\mathrm{pH}$ is hereafter reported. Furthermore, the use of an optimized mass of nanocatalyst allowed a 10 times increase of the catalytic efficiency in neutral conditions, 
leading to a final hydrogen production rate of $22.1 \mu \mathrm{mol} . \mathrm{g}^{-1} \cdot \mathrm{h}^{-1}$ in pure deionized water and under 2.2 bar of argon pressure.

\section{Materials and Methods}

\section{Materials and reagents}

The $\mathrm{TiO}_{2}$ nanoparticles $\mathrm{P} 25$ Aeroxide ${ }^{\circledR}$, particle mean size $\approx 23 \mathrm{~nm}$ (with $50 \pm 15 \mathrm{~m}^{2} / \mathrm{g}$ specific surface area) were supplied by Sigma-Aldrich.

Toluene was collected from an Innovative Technology solvent purification system and used without further purification.

Synthesis of Ag(amd) precursor and Cbz macrocyclic molecule

The silver N,N'-diisopropylacetamidinate $(\mathrm{Ag}(\mathrm{amd}))$ precursor was prepared according to a previously reported procedure [49]. The synthesis of 1,10-bis-anilinylethynyl-4,7,13,16tetraphenyl carbo-benzene (Cbz) was realized as previously reported [50].

Synthesis of triptych $\mathrm{TiO}_{2} / \mathrm{Cbz}^{2 \%} / \mathrm{Ag}^{3 \%}$

All the reactions were carried out under argon atmosphere, using Schlenk tube and vacuum line techniques.

In a standard procedure, in a glovebox (Bruker), a Fisher-Porter bottle is filled with $100.0 \mathrm{mg}$ of $\mathrm{TiO}_{2}$ and $100 \mathrm{~mL}$ of dry and degassed toluene. $\mathrm{Cbz}(18.0 \mathrm{mg})$ is then added and the mixture is stirred at room temperature in the glovebox during $15 \mathrm{~min}$, before addition of the $\mathrm{Ag}(\mathrm{amd})$ precursor $(9.0 \mathrm{mg})$. The bottle is then removed from the glovebox (at the exclusion of light) and irradiated with a UV lamp (Hg, $100 \mathrm{~W})$ during $2 \mathrm{~h}$. Then, the toluene is evaporated to dryness. The raw nanocatalyst material was then used without further purification.

Synthesis of triptychs $\mathrm{TiO}_{2} / \mathrm{Cbz}^{\mathrm{X} \%} / \mathrm{Ag}^{\mathrm{Y} \%}$ 
According to the procedure described for the synthesis of $\mathrm{TiO}_{2} / \mathrm{Cbz}^{2 \%} / \mathrm{Ag}^{3 \%}$, several nanocatalysts were prepared by varying the quantities of $\mathrm{Cbz}(1 \%, 2 \%, 3 \%)$ and $\mathrm{Ag}$ precursor $(1 \%, 3 \%, 5 \%)$, as detailed in Table S1 (see Supporting Information, SI).

\section{Materials characterization}

A set of techniques was used for the characterization of the nanocatalysts. Transmission electron microscopy (TEM) observations were carried out with a JEOL JEM 1011 microscope at $100 \mathrm{kV}$. A drop of toluene suspension of nanocatalyst was deposited on a copper microscopy grid before observations. High-Angle Annular Dark-Field Scanning Transmission Electronic Microscopy (STEM-HAADF) was used to study the samples on a JEM-ARM200F cold FEG at $200 \mathrm{kV}$ with a probe $\mathrm{Cs}$ corrector reaching a spatial correction of $0.078 \mathrm{~nm}$. Energy Dispersive X-Ray Spectrometry (EDS) spectra were recorded using a JEOL CENTURIO SDD detector. The X-ray photoelectron spectroscopy (XPS) analyses were performed in an ESCALAB 250 X-Ray photoelectron spectrometer, using $\mathrm{Mg} \mathrm{K} \alpha \mathrm{X}$-Ray as the excitation source and a concentric hemispherical electron energy analyzer under high vacuum $\left(10^{-9} \mathrm{mbar}\right)$. The samples (powders) were deposited and pressed on a tungsten mesh (wires/In.: $100 \times 100$; wire diameter: 0.001"; width opening: 0.0090") prior to the analyses. Due to the insulating property of the samples, a neutralizer beam was used during the analyses $(1 \mu \mathrm{A})$. The specific surface area has been determined by the Brunauer-Emmett-Teller (BET) method at $77 \mathrm{~K}$ using a Micromeritics ASAP2020 surface area and porosimetry Analyzer. The infrared absorption spectra were recorded with a Thermo-Nicolet FTIR instrument. The samples ( $\sim 2 \mathrm{mg}$ of powder) were pressed within $\mathrm{KBr}$ pellets and placed into a high-pressure high-temperature cell at the focal point of the sample compartment of the infrared spectrometer. The cell was connected to a vacuum-line for evacuation (base pressure $\sim 100 \mathrm{mTorr}$ ). The spectra were recorded in transmission mode between $4000 \mathrm{~cm}^{-1}$ and $400 \mathrm{~cm}^{-1}\left(4 \mathrm{~cm}^{-1}\right.$ spectral resolution) with a MCTA detector under vacuum at $30{ }^{\circ} \mathrm{C}$. Raman analyses were performed on a Nicolet Almega XR 
Raman Spectrometer equipped with a $780 \mathrm{~nm}$ laser. The powder-diffraction diagrams were obtained with a SEIFERT XRD 3000 TT X Ray diffractometer with $\mathrm{Cu}-\mathrm{K} \alpha$ radiation, fitted with a diffracted-beam graphite monochromator. The data were collected in the grazing incidence configuration $\left(3^{\circ}\right)$ and $2 \theta$ varying between 5 and $70^{\circ}$. The absorbance spectra were recorded with a Perkin-Elmer Lambda 950 UV-visible spectrometer using an integration sphere (specular mode) in the wavelength region 200-850 $\mathrm{nm}$. These spectra were recorded in transmission mode using samples mixed with $\mathrm{KBr}$ powder. The emission spectra were recorded with a Photon Technology International (PTI) Quanta Master 1 spectrofluorometer. All optical measurements were achieved with quartz cells of optical pathway $1 \mathrm{~cm}$, and all fluorescence spectra were corrected.

\section{Photocatalytic experiments}

The photocatalyst $(30 \mathrm{mg})$ was immersed in deionized water $(30 \mathrm{~mL})$ in a quartz reactor $(135$ $\mathrm{mL}$ ) equipped with a teflon layered magnetic stirrer (see SI, Figure S1) and irradiated with a solar simulator (Generator 5310 Xenon $300 \mathrm{~W}$, Eurosep ${ }^{\circledR}$ ) equipped with a liquid lightguide (Lumatec $^{\circledR}$, series 380, $8 \mathrm{~mm} \times 150 \mathrm{~mm}$, from the near UV to the far red, 3,6 W, Eurosep ${ }^{\circledR}$, see SI, Figure S2). Note that the samples were placed at $\sim 2 \mathrm{~cm}$ from the liquid lightguide which corresponds to an optical irradiance at the sample of $200 \mathrm{~mW} \cdot \mathrm{cm}^{-2}$ at $365 \mathrm{~nm}$ and 800 $\mathrm{mW} \cdot \mathrm{cm}^{-2}$ at $405 \mathrm{~nm}$. The relative spectra distribution of the Xenon lamp is showed in Figure S2, where the reactor is connected in line to a gas chromatography (GC) system (Perkin-Elmer ${ }^{\circledR}$ Clarus 580, PlotQ column $(30 \mathrm{~m})$ and PE-molsieve column $(30 \mathrm{~m})$, thermal detector conductivity (TCD) detector, vector gas: argon), and a small amount (20 $\mu \mathrm{L})$ of the gaseous atmosphere of the reactor is injected for analysis. The reactor was purged and pressurized at 2.2 bar under argon gas prior to irradiation until disappearance of oxygen and nitrogen peaks (analyzed by GC). The GC analyses were performed every $6 \mathrm{~h}$ to monitor the hydrogen production. 


\section{Results and Discussion}

\section{Synthesis and characterization of the triptych $\mathrm{TiO}_{2} / \mathrm{Cbz}^{2 \%} / \mathrm{Ag}^{3 \%}$ nanocatalyst}

The $\mathrm{TiO}_{2} / \mathrm{Cbz}^{2 \%} / \mathrm{Ag}^{3 \%}$ triptych was synthesized in two steps. First, commercial Aeroxide ${ }^{\circledR}$ $\mathrm{TiO}_{2}$ NPs $(\sim 23 \mathrm{~nm})$ were impregnated with a toluene solution of the $\mathrm{Cbz}$ dye in order to have a maximum coverage of the $\mathrm{TiO}_{2} \mathrm{NPs}$ surface by a photosensitive layer of Cbz. Then the growth of Ag NPs by photo-decomposition of $\mathrm{Ag}(\mathrm{amd})$ under UV light was performed in order to assemble the third component of the triptych (Figure 1).

Transmission electron microscopy (TEM) and high-angle annular dark-field scanning transmission electronic microscopy (STEM-HAADF) images show the formation of spherical Ag NPs of $5.4 \pm 1.3 \mathrm{~nm}$ mean size which are exclusively deposited on the $\mathrm{TiO}_{2} / \mathrm{Cbz}$ surface (i.e. no free Ag NPs are observed without $\mathrm{TiO}_{2} \mathrm{NP}$ on the grid, Figure 2a). The growth of silver nanoparticles is realized by adsorption and decomposition of the photosensitive $\operatorname{Ag}(\mathrm{amd})$ precursor under UV light. While most of the Ag NPs are found in direct contact with the $\mathrm{TiO}_{2}$ surface, revealing migration through the Cbz layer, a few of them are embedded within the organic layer (Figure 2b). The growth of crystalline $\mathrm{Ag}^{0}$ NPs (111 crystallographic planes) on the $\mathrm{TiO}_{2} \mathrm{NP}$ surface is confirmed by STEM-HAADF observations (Figure 2c) and EDS measurements (see SI, Figure S3).

According to TEM, the $\mathrm{Cbz}$ thin layer thus plays the role of a stabilizing agent for the $\mathrm{Ag}$ NPs (Figure 2b) [43]. Note that the comparison between STEM-HAADF images taken in bright and dark field modes allows the clear pinpointing of the Cbz layer (Figure 2c). The homogeneity of the Cbz layer thickness ( $\sim 2 \mathrm{~nm}$ thick) is remarkable and corresponds roughly to the distance between the two $-\mathrm{NH}_{2}$ groups of the $\mathrm{Cbz}$ molecule (Figure 2e). 


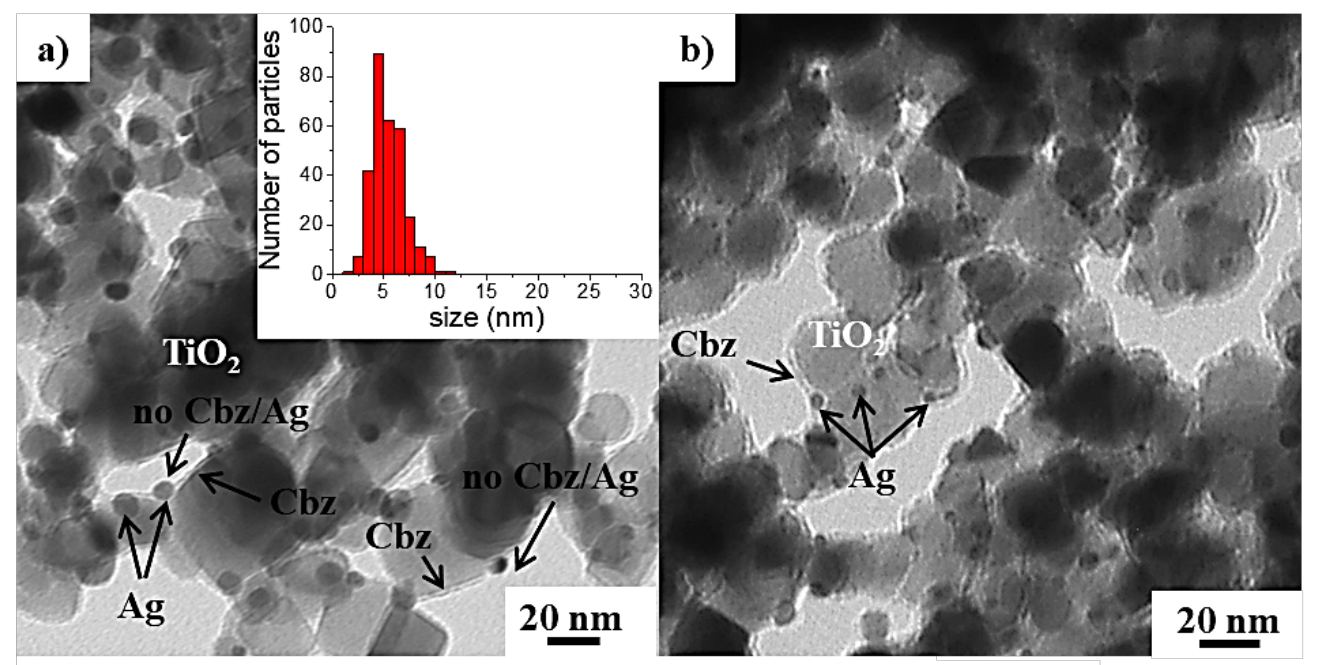

c) $\mathrm{TiO}_{2} / \mathrm{Cbz}^{2 \%} / \mathrm{Ag}^{3 \%}$ before photocatalysis

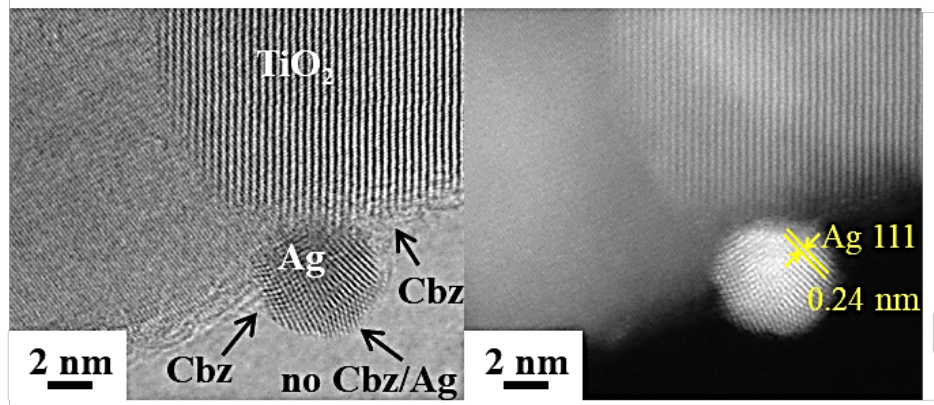

e) $\mathrm{Cbz}$

d) $\mathrm{TiO}_{2} / \mathrm{Cbz}^{2 \%} / \mathrm{Ag}^{3 \%}$ after photocatalysis
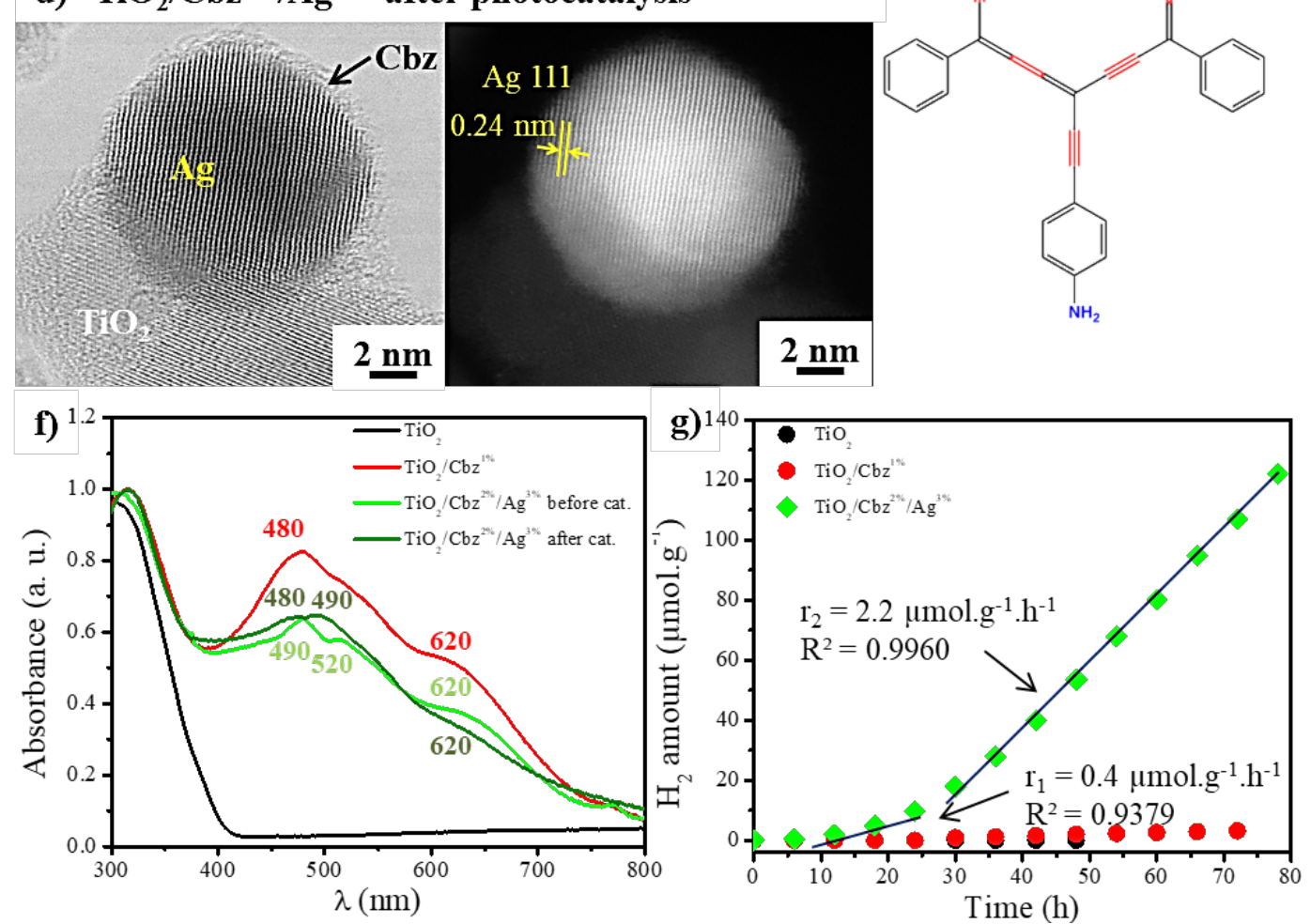

Figure 2. $a$-b) TEM images (inset of the size dispersion of Ag NPS) and STEM-HAADF images taken in bright (on the left) and dark field (on the right) c) before, and d) after photocatalysis 
for $\mathrm{TiO}_{2} / \mathrm{Cbz}^{2 \%} / \mathrm{Ag}^{3 \%}$ nanocatalyst; e) molecular structure of $\mathrm{Cbz}$; f) combined normalized solid $\mathrm{UV}$-visible spectra of triptych $\mathrm{TiO}_{2} / \mathrm{Cbz}^{2 \%} / \mathrm{Ag}^{3 \%}$ before (light green curve) and after (dark green curve) photocatalysis, with comparison to $\mathrm{TiO}_{2} \mathrm{P} 25$ Aeroxide $^{\circledR}$ (black curve) and $\mathrm{TiO}_{2} / \mathrm{Cbz}_{\text {(red }}$ curve) references ( $\mathrm{KBr}$ solid dilution); g) $\mathrm{H}_{2}$ production of $\mathrm{TiO}_{2}$ (black), $\mathrm{TiO}_{2} / \mathrm{Cbz}$ (red) and triptych $\mathrm{TiO}_{2} / \mathrm{Cbz}^{2 \%} / \mathrm{Ag}^{3 \%}$ nanocatalyst (green).

The $\mathrm{TiO}_{2}$ stoichiometry $\mathrm{TiO}_{2} / \mathrm{Cbz}^{2 \%} / \mathrm{Ag}^{3 \%}$ is confirmed by XPS analysis giving binding energies of the Ti $2 \mathrm{p}_{1 / 2}$, Ti $2 \mathrm{p}_{3 / 2}$ and $\mathrm{O} 1 \mathrm{~s}$ core levels at $465.8,460.1 \pm 0.1$ and $532.8 \mathrm{eV}$, respectively (see SI, Figures S4-6). Silver integration in the triptych nanomaterial is confirmed by the binding energies of the $\mathrm{Ag} 3 \mathrm{~d}_{3 / 2}, \mathrm{Ag} 3 \mathrm{~d}_{5 / 2}$ core levels at 374.7 and $368.7 \mathrm{eV}$, respectively. Thanks to the $\mathrm{TiO}_{2}$ and $\mathrm{Cbz}$ XPS reference spectra, the binding energies measured at 285.5 and $400.7 \mathrm{eV}$ are assigned to C 1s and N 1s core levels, respectively (see SI, Section B-2).

A specific surface of $37.07 \mathrm{~m}^{2} \cdot \mathrm{g}^{-1}$ for this triptych $\mathrm{TiO}_{2} / \mathrm{Cbz}^{2 \%} / \mathrm{Ag}^{3 \%}$ nanocatalyst, as determined by Brunauer-Emmet-Teller (BET) measurement, is lower than the specific surface

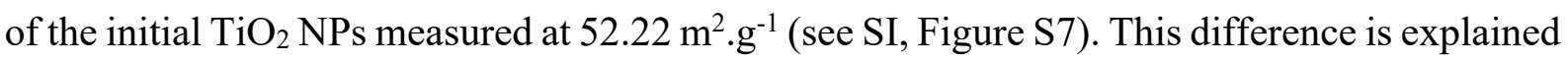
by the agglomeration of the triptych nanocatalyst, as it can be observed in the TEM images (Figure 2a,b).

The IR spectra of $\mathrm{TiO}_{2} \mathrm{P} 25$ Aeroxide ${ }^{\circledR}, \mathrm{Cbz}$ and $\mathrm{TiO}_{2} / \mathrm{Cbz}^{2 \%} / \mathrm{Ag}^{3 \%}$ can be compared in a systematic manner (see SI, Section B-4). The IR spectrum of $\mathrm{TiO}_{2} / \mathrm{Cbz}^{2 \%} / \mathrm{Ag}^{3 \%}$ shows a sharp mode at $3389 \mathrm{~cm}^{-1}$ assigned to the $-\mathrm{NH}_{2}$ stretch mode of $\mathrm{Cbz}$, two modes at 2188 and $2118 \mathrm{~cm}^{-}$ ${ }^{1}$ (both assigned to exo and endo macrocyclic $\mathrm{C} \equiv \mathrm{C}$ stretch vibration) [51], at least five sharp modes in the $1620-1510 \mathrm{~cm}^{-1}$ region assigned to $\mathrm{C}=\mathrm{C}$ stretch vibrations, three main peaks in the $1200-1100 \mathrm{~cm}^{-1}$ region assigned to aromatic $\mathrm{C}=\mathrm{C}$ bend vibrations of $\mathrm{Cbz}$ phenyl groups and a broad and intense peak at $\sim 700 \mathrm{~cm}^{-1}$ assigned to the Ti-O vibration (see SI, Figure S8). In the 
triptych system, the intensities of the Cbz vibration modes are found to decrease due to the low quantity of $\mathrm{Cbz}(2 \%)$ in the nanocatalyst. Note that the broad and intense Ti-O mode hides the Cbz modes in the 1000-600 $\mathrm{cm}^{-1}$ region, which corresponds to the aromatic bend (out of plan vibration) of the phenyl groups of the $\mathrm{Cbz}$ (for the molecular structure of the $\mathrm{Cbz}$, see Figure 2e).

Raman spectra of $\mathrm{TiO}_{2} / \mathrm{Cbz}^{2 \%} / \mathrm{Ag}^{3 \%}$ show a series of peaks at 2029, 1598, 1326, 1116 and $633 \mathrm{~cm}^{-1}$, and many others in the $475-220 \mathrm{~cm}^{-1}$ region (see SI, Figure S9), which are assigned to the Cbz molecule [51]. A thin and intense peak is also observed at $150 \mathrm{~cm}^{-1}$, corresponding to the $\mathrm{E}_{\mathrm{g} 1}$ phonon mode of $\mathrm{TiO}_{2}$, which is blue-shifted $\left(+4.0 \mathrm{~cm}^{-1}\right)$ as compared to the reference, as expected for the formation of a $\mathrm{TiO}_{2} / \mathrm{Ag}$ interface. Indeed, such a blue-shift has been previously described for $\mathrm{TiO}_{2} / \mathrm{Au}$ materials and is known to favor the charge transfer interactions between the $\mathrm{TiO}_{2}$ and metallic NPs [52]. In the case of triptych $\mathrm{TiO}_{2} / \mathrm{Ag} / \mathrm{Cbz}$ thin films, a similar blue-shift was also observed when the pores of an anatase $\mathrm{TiO}_{2}$ film were filled by Ag NPs [43], demonstrating the close structural relationship between the $\mathrm{TiO}_{2}$ and $\mathrm{Ag}$ crystalline networks [53]: the blue-shift strongly suggests a covalent grafting of the Ag NPs onto the $\mathrm{TiO}_{2}$ NP surface.

The X-Ray Diffraction (XRD) analysis of $\mathrm{TiO}_{2} / \mathrm{Cbz}^{2 \%} / \mathrm{Ag}^{3 \%}$ (see SI, Figure S10) shows only peaks corresponding to the anatase/rutile crystallographic phases of $\mathrm{TiO}_{2}(79 \%$ anatase $/ 21 \%$ rutile): the Ag nanocrystals are too small to be detected by $\mathrm{XRD}$, and the $\mathrm{Cbz}$ layer is not crystalline. From the solid UV-visible spectrum of $\mathrm{TiO}_{2} / \mathrm{Cbz}^{2 \%} / \mathrm{Ag}^{3 \%}$ (light green curve, Figure 2f), application of the Kubelka-Munk function brings out the strong band-gap absorption of $\mathrm{TiO}_{2} \mathrm{NPs}$ around $2.9 \mathrm{eV}$. Moreover, the two main absorbance bands of the $\mathrm{Cbz}$ observed around $490 \mathrm{~nm}$ and $620 \mathrm{~nm}$ are in agreement with the UV-visible spectrum of the Cbz both in the solid 
state (red curve, Figure 2f) and in toluene solution [50]. The main absorption band of the $\mathrm{Cbz}$ at $490 \mathrm{~nm}$ corresponds to the overlap of two transitions (HOMO-1/HOMO $\rightarrow$ LUMO/LUMO+1) following the Gouterman four-orbital model described for the interpretation of the electronic spectra of porphyrins [54-57]. Finally, the contribution of the Ag NPs localized surface plasmon resonance (LSPR) appears around $520 \mathrm{~nm}$, as expected for Ag NPs of $c a 5.4$ $\pm 1.3 \mathrm{~nm}$ size on $\mathrm{TiO}_{2}$, and overlaps with one of the absorption bands of the $\mathrm{Cbz}[15,58]$.

The photocatalytic reduction of water was investigated under a high pressure of argon (2.2 bar) which is unfavorable for the $\mathrm{H}_{2}$ production $[45,59]$, but closer to practical applications [44]. Though a weak $\mathrm{H}_{2}$ production rate is measured during the first $20 \mathrm{~h}$ of irradiation $\left(\mathrm{H}_{2}\right.$ production rate: $\mathrm{r}_{1}=0.4 \mu \mathrm{mol} \cdot \mathrm{g}^{-1} \cdot \mathrm{h}^{-1}$ in pure deionized water), this rate becomes more than 5 times higher $\left(\mathrm{H}_{2}\right.$ production rate: $\mathrm{r}_{2}=2.2 \mu \mathrm{mol} \cdot \mathrm{g}^{-1} \cdot \mathrm{h}^{-1}$, Figure $\left.2 \mathrm{~g}\right)$ after this activation period (i.e. during the following $60 \mathrm{~h}$ ). Hydrogen production measurements for the $\mathrm{TiO}_{2} \mathrm{P} 25$ Aeroxide ${ }^{\circledR}$ and the diptych $\mathrm{TiO}_{2} / \mathrm{Cbz}^{1 \%}$ nanocatalyst have been performed with reference samples tested in the same conditions for comparison. While there is no hydrogen production for $\mathrm{TiO}_{2} \mathrm{P} 25$ Aeroxide ${ }^{\circledR}$ after $48 \mathrm{~h}$ of irradiation, the $\mathrm{TiO}_{2} / \mathrm{Cbz}^{1 \%}$ system begins to produce a very small but measurable amount of hydrogen after $30 \mathrm{~h}$ of irradiation, at a rate of $0.08 \mu \mathrm{mol. \textrm {g } ^ { - }}$ ${ }^{1} \cdot \mathrm{h}^{-1}$ (Figure $2 \mathrm{~g}$ ).

The triptych $\mathrm{TiO}_{2} / \mathrm{Cbz}^{2 \%} / \mathrm{Ag}^{3 \%}$ nanocatalyst has also been characterized after a $60 \mathrm{~h}$ photocatalysis (PC) experiment performed in pure deionized water under irradiation: the TEM images show a slight increase of the Ag NPs size (with a dispersion of size after PC of $8.4 \pm$ $2.2 \mathrm{~nm}$ ). The STEM-HAADF analysis indicates that the Cbz layer completely covers the $\mathrm{TiO}_{2}$ and Ag NPs (Figure 2d), which was not the case before PC. The XRD analysis (see SI Figure S10) shows that two novel peaks are evidenced at $18^{\circ}$ and $32^{\circ}$ respectively, which may be 
attributed to the formation of a crystalline Cbz layer [60]. Hypsochromic shifts of $10 \mathrm{~nm}$ for the main absorption band of $\mathrm{Cbz}$ at $480 \mathrm{~nm}$ (dark green curve, Figure 2f) and of $30 \mathrm{~nm}$ for the LSPR band ( 490 nm) of the Ag NPs are also observed in the UV-visible spectrum. This last shift is assigned to the environment change of Ag NPs due to the presence of the Cbz layer after PC, thus affecting their LSPR properties [61]. Furthermore, the changes observed in the photoluminescence spectra after photocatalysis suggest a modification of the surface of the triptych photocatalyst (see SI, Figure S11). The consideration of both the post-catalysis characterization and the layout of $\mathrm{H}_{2}$ production rate allows us hypothesizing that a reorganization of the $\mathrm{Cbz}$ layer occurs onto the surface of the triptych nanocatalyst during the first hours of the PC.

\section{Influence of the thickness of the Cbz layer in the triptych nanocatalysts}

For a better appraisal of the $\mathrm{Cbz}$ reorganization process, investigations were carried out in the presence of a lower amount of $\mathrm{Cbz}$ in the triptych nanocatalyst: $1 \%$ molar amount of $\mathrm{Cbz}$ is actually just sufficient to offer a full covering of the $\mathrm{TiO}_{2}$ surface. Importantly, the UV-visible analysis detects no free Cbz in solution after impregnation (see SI, Figure S12).

The TEM images of the triptych $\mathrm{TiO}_{2} / \mathrm{Cbz}^{1 \%} / \mathrm{Ag}^{3 \%}$ (see SI, Figure S13b) evidence the growth of $\mathrm{Ag}$ NPs onto the $\mathrm{TiO}_{2}$ surface by photo-decomposition of $\mathrm{Ag}(\mathrm{amd})$ as it is observed with $\mathrm{TiO}_{2} / \mathrm{Cbz}^{2 \%} / \mathrm{Ag}^{3 \%}$ (Figure 2a,b). However, a slight increase of the Ag NPs size (distribution size of $6.5 \pm 2.2 \mathrm{~nm}$ ) due to the twice lower amount of Cbz is noticed: indeed, the NPs size is known to increase when the amount of stabilizing agent is reduced [62], thus highlighting the key stabilizing role of the Cbz during the growth of Ag NPs. The photocatalytic production of hydrogen has been monitored in pure deionized water with the $\mathrm{TiO}_{2} / \mathrm{Cbz}^{1 \%} / \mathrm{Ag}^{3 \%}$ nanocatalyst (Figure $3 \mathrm{c}$ ) and, here again, a first period $(12 \mathrm{~h})$ of a low catalysis rate $\left(0.5 \mu \mathrm{mol} \cdot \mathrm{g}^{-1} \cdot \mathrm{h}^{-1}\right)$ is 
observed. After this initiation period, the catalytic performance increases up to $1.6 \mu \mathrm{mol} . \mathrm{g}^{-1} \cdot \mathrm{h}^{-}$ ${ }^{1}$ (by a factor $>3$ ), and before the $\mathrm{H}_{2}$ production rate remains constant over the following $60 \mathrm{~h}$ (Figure 3a), thus indicating a possible end of the reorganization process, as previously noticed. To investigate this phenomenon, spectroscopic characterization (XPS, Raman, IR) has been done before and after PC experiments.

XPS analysis of the $\mathrm{TiO}_{2} / \mathrm{Cbz}^{1 \%} / \mathrm{Ag}^{3 \%}$ nanocatalyst before and after PC (see SI, Figure S14S15) shows a shift of the Ti $2 p_{1 / 2 ; 3 / 2}$ peak $(+0.2 \mathrm{eV}), \operatorname{Ag} 3 \mathrm{~d}_{3 / 2 ; 5 / 2}$ peak $(+0.1 \mathrm{eV})$ and $\mathrm{C} 1 \mathrm{~s}$ peak $(+0.1 \mathrm{eV})$ whereas no change is observed for the $\mathrm{O} 1 \mathrm{~s}$ peak. More importantly, the highest shift is measured for the $\mathrm{N} 1 \mathrm{~s}$ peak $(+0.3 \mathrm{eV})$, clearly indicating a difference of coordination of the $-\mathrm{NH}_{2}$ groups of the $\mathrm{Cbz}$ with $\mathrm{TiO}_{2}$ and/or Ag NPs. In the IR spectra recorded before and after PC (see SI, Figure S15), the intensities of the $\mathrm{C} \equiv \mathrm{C}$ stretch vibration modes are very weak because of the lower content of $\mathrm{Cbz}$ in $\mathrm{TiO}_{2} / \mathrm{Cbz}^{1 \%} / \mathrm{Ag}^{3 \%}$ as compared to $\mathrm{TiO}_{2} / \mathrm{Cbz}^{2 \%} / \mathrm{Ag}^{3 \%}$ (see SI, Figure S8).

Raman spectroscopy also affords evidence of the reorganization of Cbz during PC since an increase in intensity of all the vibration modes of Cbz is observed after PC (see SI, Figure S17). Notably, the aromatic $\mathrm{C}=\mathrm{C}$ stretch vibration mode is more intense and shifted from 1581 to $1604 \mathrm{~cm}^{-1}$. Similarly, the $\mathrm{C} \equiv \mathrm{C}$ stretch vibration modes of Cbz appear after PC at 2141 and 2034 $\mathrm{cm}^{-1}$ whereas there are not observed before PC (see SI, Figure S17). These observations suggest an enhancement of the Cbz Raman signals by surface enhancement Raman scattering (SERS) effect $[48,63,64]$, as a result of the stronger coordination interactions between the $\mathrm{Cbz}-\mathrm{NH}_{2}$ groups and the Ag NPs surface, already shown by XPS characterization. The reorganization of the Cbz molecules modifies the Ag NPs surface, thus inducing the observed SERS effect. This reorganization of the $\mathrm{Cbz}$ molecules leads to the formation of a continuous and homogeneous photosensitive thin organic layer $(\sim 2 \mathrm{~nm})$ covering both $\mathrm{Ag}$ and $\mathrm{TiO}_{2} \mathrm{NPs}$ and is correlated with the observed enhancement of the hydrogen production rate from pure deionized water with both 
$\mathrm{TiO}_{2} / \mathrm{Cbz}^{1 \%}$ and $2 \% / \mathrm{Ag}^{3 \%}$ nanocatalysts (from 0.5 to 1.6 and from 0.4 to $2.2 \mu \mathrm{mol} \cdot \mathrm{h}^{-1} \cdot \mathrm{g}^{-1}$ respectively, Figures $2 \mathrm{~g}$ and $3 \mathrm{c}$ ). Furthermore, STEM-HAADF observations, fast Fourier transform (FFT) (Figure 2c,d) and Raman spectroscopy (see SI, Figure S17) after PC do not evidence any oxidation of the Ag NPs, i.e. the nanoparticles are still composed of metallic $\mathrm{Ag}^{0}$. Finally, the reorganized Cbz layer may play a double role: $i$ ) it helps to harvest a large part of the UV-visible light (with a strong absorption in the visible region) and allows lowering the recombination of photo-induced electron/hole pairs $[46,47,50]$, and ii) it forms a protective organic layer around the NPs, thus preventing their oxidation and degradation by photocorrosion in time $[65,66]$.

The effect of the Cbz layer was then highlighted through the synthesis and characterization of the $\mathrm{TiO}_{2} / \mathrm{Cbz}^{3 \%} / \mathrm{Ag}^{3 \%}$ triptych, i.e. containing a relatively large amount of $\mathrm{Cbz}$. The combined normalized solid UV-visible spectra of triptychs $\mathrm{TiO}_{2} / \mathrm{Cbz}^{1,2}$ and $3 \% / \mathrm{Ag}^{3 \%}$ do not show any proportional increase of the main absorption bands of the Cbz with the amounts of this PS used (Figure 3a): similar profiles are observed for the triptych nanocatalysts containing $1 \%$ and $3 \%$ of $\mathrm{Cbz}$, while the spectrum of the $2 \% \mathrm{Cbz}$ triptych $\left(\mathrm{TiO}_{2} / \mathrm{Cbz}^{2 \%} / \mathrm{Ag}^{3 \%}\right)$ exhibits bands of lower intensities $(\lambda=480$ and $620 \mathrm{~nm}$, Figure 3a). The photocatalytic activity of the $\mathrm{TiO}_{2} / \mathrm{Cbz}^{3 \%} / \mathrm{Ag}^{3 \%}$ triptych has also been monitored (Figure 3c), showing a higher hydrogen production rate in the first $30 \mathrm{~h}$ (at a rate of $\left.1.7 \mu \mathrm{mol} . \mathrm{g}^{-1} \cdot \mathrm{h}^{-1}\right)$, as compared with the two other triptychs, but the catalysis rate begins to decrease after this period $\left(0.6 \mu \mathrm{mol} \cdot \mathrm{g}^{-1} \cdot \mathrm{h}^{-1}\right.$, Figure $\left.3 \mathrm{c}\right)$. Two main explanations of this decrease can be proposed: a too thick Cbz layer may thus $i$ ) increase the number of $\mathrm{Cbz}$ molecules that have to be reorganized under illumination and the kinetic is too slow, and $i$ ) generate a too hydrophobic layer, which may result in the aggregation of the nanocatalyst and reduce its active surface area. 
Finally, a faster reorganization of the photosensitive $\mathrm{Cbz}$ layer is noticed with the $1 \% \mathrm{Cbz}$ triptych compared to the other triptych nanocatalysts, assuming that the change of the catalytic rate of hydrogen production occurs only after complete reorganization of the $\mathrm{Cbz}$ layer, as previously demonstrated (i.e. the rate change occurs after $12 \mathrm{~h}, 20 \mathrm{~h}$ and $30 \mathrm{~h}$ for the triptych $\mathrm{TiO}_{2} / \mathrm{Cbz}^{1 \%, 2 \% \text { and } 3 \%} / \mathrm{Ag}^{3 \%}$, respectively). The final catalysis rate is then still the highest for the $\mathrm{TiO}_{2} / \mathrm{Cbz}^{2 \%} / \mathrm{Ag}^{3 \%}$ nanocatalyst $\left(2.2 \mu \mathrm{mol} . \mathrm{g}^{-1} \cdot \mathrm{h}^{-1}\right.$ vs $1.6 \mu \mathrm{mol} . \mathrm{g}^{-1} \cdot \mathrm{h}^{-1}$ and $0.6 \mu \mathrm{mol} . \mathrm{g}^{-1} \cdot \mathrm{h}^{-1}$ for $\mathrm{TiO}_{2} / \mathrm{Cbz}^{1 \%} / \mathrm{Ag}^{3 \%}$ and $\mathrm{TiO}_{2} / \mathrm{Cbz}^{3 \%} / \mathrm{Ag}^{3 \%}$, respectively, Figure 3e). This result clearly demonstrates the important role of the thickness of the photosensitive $\mathrm{Cbz}$ layer coordinated onto the $\mathrm{TiO}_{2}$ surface. 


$$
\mathrm{TiO}_{2} / \mathrm{Cbz}^{\mathrm{Y} \%} / \mathrm{Ag}^{3 \%}(\mathrm{Y}=1,2 \text { and } 3 \%) \quad \mathrm{TiO}_{2} / \mathrm{Cbz}^{1 \% / \mathrm{Ag}^{\mathrm{X}} \%}(\mathrm{X}=\mathbf{0 , 1 , 3} \text { and } 5 \%)
$$
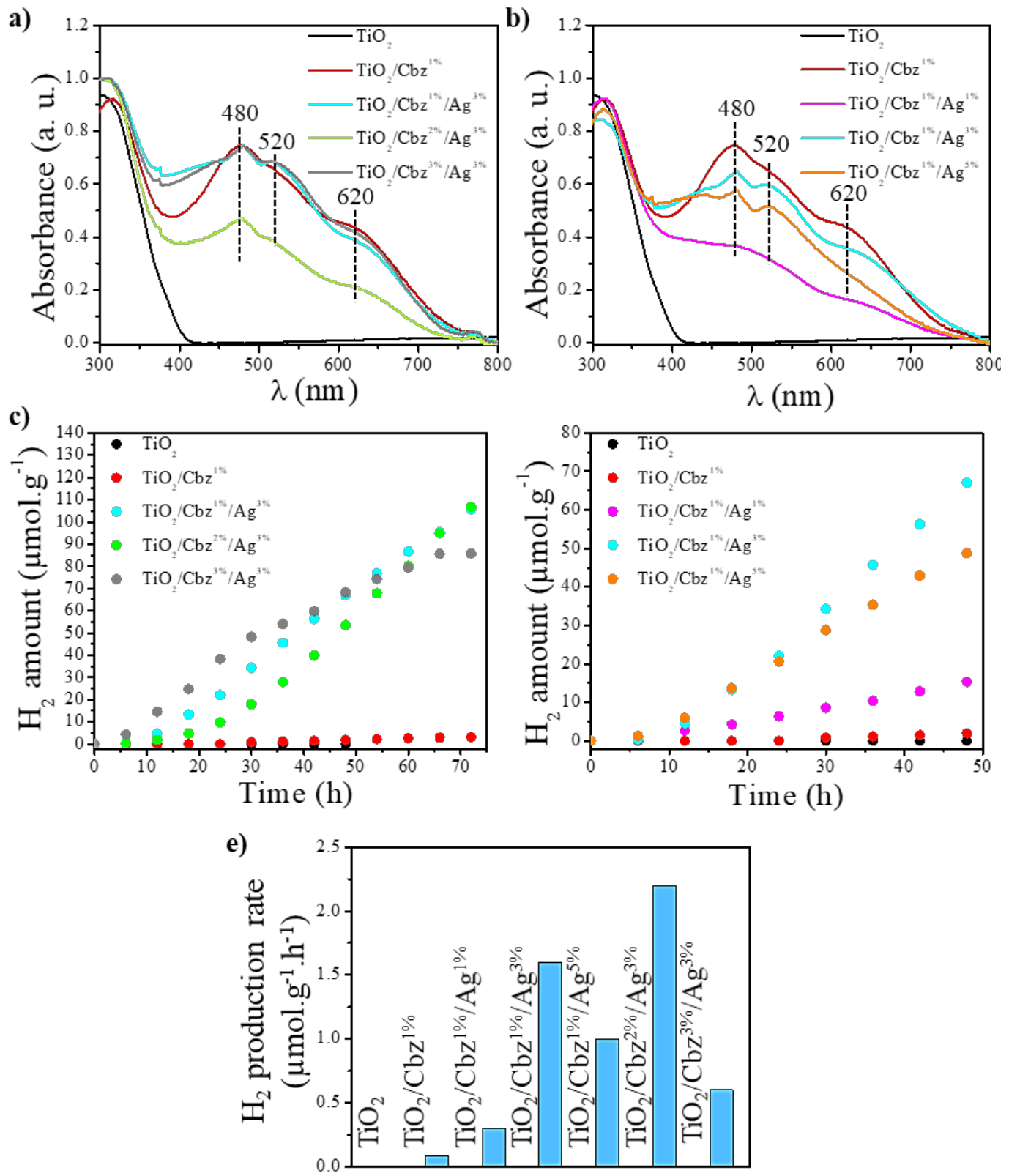

Figure 3. Combined normalized solid UV-visible spectra of $\mathrm{TiO}_{2}$ (black curve), $\mathrm{TiO}_{2} / \mathrm{Cbz}^{1 \%}$ (red curve), a) the triptych $\mathrm{TiO}_{2} / \mathrm{Cbz}^{\mathrm{Y} \%} / \mathrm{Ag}^{3 \%}$ series ( $\mathrm{Y}=1$ (cyan curve), 2 (green curve) and $3 \%$ (grey curve)) (samples prepared by dilution with $\mathrm{SiO}_{2}$ ) and b) the triptych $\mathrm{TiO}_{2} / \mathrm{Cbz}^{1 \%} / \mathrm{Ag}^{\mathrm{X} \%}$ series ( $X=1$ (pink curve), 3 (cyan curve) and 5\% (orange curve)) (samples prepared by solid dilution with $\mathrm{KBr}$ ); $\mathrm{H}_{2}$ production with the triptychs c) $\mathrm{TiO}_{2} / \mathrm{Cbz}^{\mathrm{l}, 2}$ and $3 \% / \mathrm{Ag}^{3 \%}$ and d) $\mathrm{TiO}_{2} / \mathrm{Cbz}^{1 \%} / \mathrm{Ag}^{\mathrm{l}, 3}$ and $5 \%$ nano-catalysts series immersed into pure deionized water at room 
temperature and pressurized under argon at 2.2 bar; e) comparison of the final catalytic rate of $\mathrm{H}_{2}$ production (in $\mu \mathrm{mol} . \mathrm{g}^{-1} \cdot h^{-1}$ ) for all the studied triptych nanocatalysts.

\section{Influence of the amount of Ag in the triptych nanocatalysts}

After having highlighted the importance of the thickness of the Cbz layer, the effect of the quantity of Ag NPs has been studied. The amount of $\mathrm{Ag}(\mathrm{amd})$ precursor was thus varied from $1 \%$ to $3 \%$ and $5 \%$ (see SI, Section A.1). The use of $1 \% \mathrm{Cbz}$ is here preferred, allowing sufficient covering of the NPs, but without release of free Cbz in the medium. The TEM observations of these three triptych $\mathrm{TiO}_{2} / \mathrm{Cbz}^{1 \%} / \mathrm{Ag}^{1,3}$ or $5 \%$ nanocatalysts evidence that the mean size and size dispersion of Ag NPs increase with the concentration of the $\mathrm{Ag}(\mathrm{amd})$ precursor: $6.2 \pm 1.6 \mathrm{~nm}$, $6.5 \pm 2.2 \mathrm{~nm}$ and $7.1 \pm 2.5 \mathrm{~nm}$ for $\mathrm{TiO}_{2} / \mathrm{Cbz}^{1 \%} / \mathrm{Ag}^{1,3}$ and $5 \%$ respectively (see SI, Figure S13a-c). A more accurate control of the Ag NPs size is achieved with the lowest amount of Ag(amd) precursor (1\%). The formation of Ag NPs from $\mathrm{Ag}(\mathrm{amd})$ might result from the oxidation of the amidinate ligand to acetyl/hydrazide imine/amidine derivatives, which could participate to the stabilization of Ag NPs in the first coordination sphere: consequently, the Cbz might only occur in the second coordination sphere for the stabilization of Ag NPs [48]. The presence of amidine oxidation products can indeed be partly responsible for the observed incomplete coverage of the Ag NPs surface by the Cbz (Figure 2c). The reorganization of the PS layer around the NPs is possibly concomitant with the expulsion of those amidine-derived byproducts by the Cbz, finally leading to the formation of a homogeneous PS layer fully wrapping the NPs.

The solid UV-visible spectra show, as expected, an increase of the Ag Np LSPR band at 520 $\mathrm{nm}$ when the amount of $\mathrm{Ag}(\mathrm{amd})$ precursor is used in larger amount (Figure 3b). The two main Cbz absorption bands are observed for all the $\mathrm{TiO}_{2} / \mathrm{Cbz}^{1 \%} / \mathrm{Ag}^{1,3}$ or $5 \%$ nanocatalysts at about 480 and $620 \mathrm{~nm}$, as in the diptych $\mathrm{TiO}_{2} / \mathrm{Cbz}^{1 \%}$ (i.e. without added $\mathrm{Ag}(\mathrm{amd})$ ). 
The photocatalytic production of hydrogen was monitored over at least $48 \mathrm{~h}$, evidencing in all cases the already observed two-phase process, i.e. an initiation period of about $12 \mathrm{~h}$ of low catalysis rate followed by an increase of this rate by a factor of $1.5,4$ and 2 , leading to a final $\mathrm{H}_{2}$ production rate of $0.3,1.6$ and $1.0 \mu \mathrm{mol} \cdot \mathrm{g}^{-1} \cdot \mathrm{h}^{-1}$ for $\mathrm{TiO}_{2} / \mathrm{Cbz}^{1 \%} / \mathrm{Ag}^{1,3}$ and $5 \%$, respectively (Figure 3d). The most efficient nanocatalyst of the series in pure deionized water appears to be $\mathrm{TiO}_{2} / \mathrm{Cbz}^{1 \%} / \mathrm{Ag}^{3 \%}$, but the highest catalytic rate remains for $\mathrm{TiO}_{2} / \mathrm{Cbz}^{2 \%} / \mathrm{Ag}^{3 \%}\left(2.2 \mu \mathrm{mol} . \mathrm{g}^{-1} \cdot \mathrm{h}^{-}\right.$ 1, Figure 3e). A too high coverage of the $\mathrm{TiO}_{2} \mathrm{NPs}$ surface by larger amounts of Ag NPs drastically reduces the accessibility of the photoactive surface not only to water but also to light, the Ag NPs shielding UV light absorption by the $\mathrm{TiO}_{2} \mathrm{SC}$ [67]. Indeed, the size of the Ag NPs is known to be an important parameter for efficient general catalysis [68-72]. A 3\% amount of Ag thus allows promoting the photocatalytic reduction of water while avoiding the decrease of the $\mathrm{TiO}_{2}$ photo-active surface area. 


\section{Optimization of the photocatalytic conditions}

a)

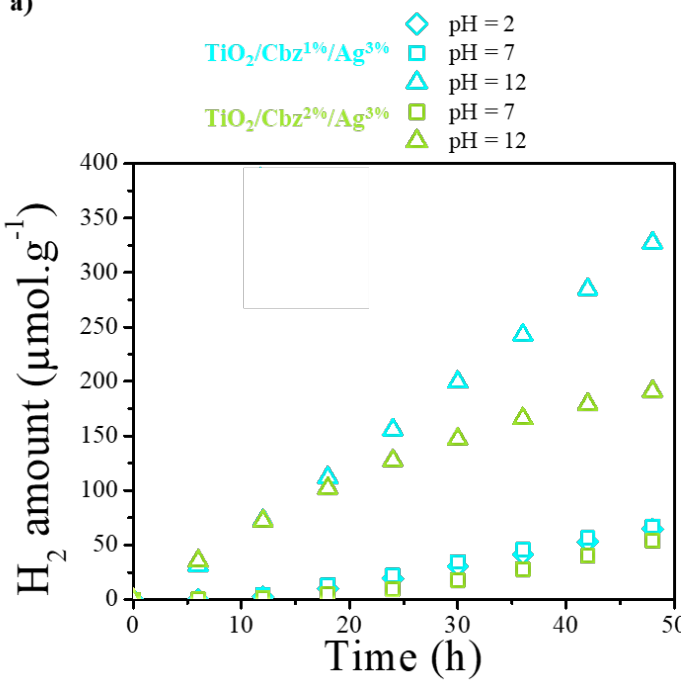

c) $\mathrm{TiO}_{2} / \mathbf{C b z}^{2 \%} / \mathbf{A g}^{3 \%} \square$ Initial catalytic rate

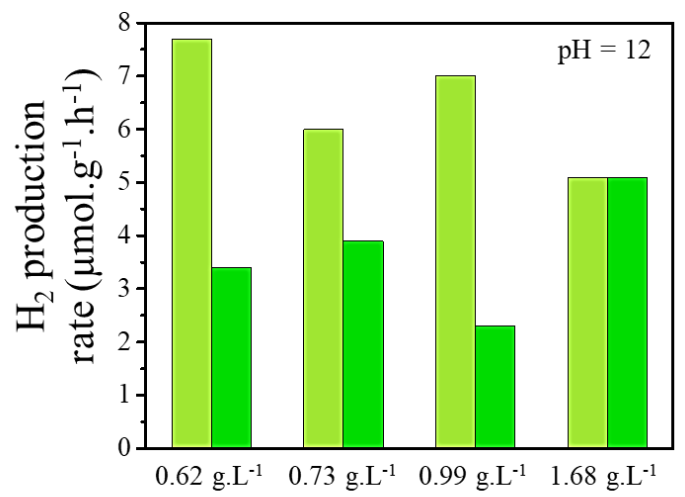

b)
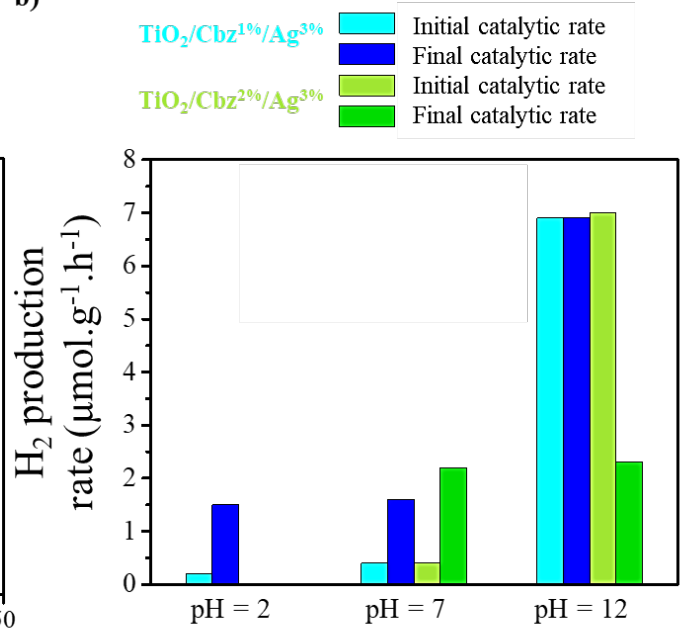

d)

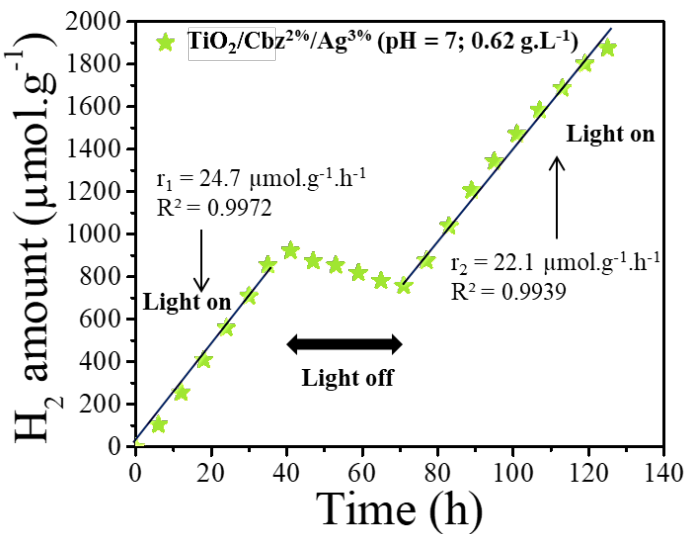

Figure 4. a) $\mathrm{H}_{2}$ production of the triptych $\mathrm{TiO}_{2} / \mathrm{Cbz}^{1 \%} / \mathrm{Ag}^{3 \%}$ (cyan curves) and $\mathrm{TiO}_{2} / \mathrm{Cbz}^{2 \%} / \mathrm{Ag}^{3 \%}$ (green curves) nanocatalysts, depending on the $\mathrm{pH}\left(\mathrm{pH}=2\right.$ : diluted aqueous $\mathrm{H}_{2} \mathrm{SO}_{4}$ solution (diamond symbols), $p H=7$ : deionized water (square symbols) and $p H=12:$ diluted aqueous $\mathrm{NaOH}$ solution (triangle symbols) at 2.2 bar of argon gas; b) comparison of the initial and final catalytic rates for the triptych $\mathrm{TiO}_{2} / \mathrm{Cbz}^{1 \%} / \mathrm{Ag}^{3 \%}$ (cyan bars) and $\mathrm{TiO}_{2} / \mathrm{Cbz}^{2 \%} / \mathrm{Ag}^{3 \%}$ (green bars) nanocatalysts depending on the $\mathrm{pH}$; c) comparison of the initial and final catalytic rates for $\mathrm{TiO}_{2} / \mathrm{Cbz}^{2 \%} / \mathrm{Ag}^{3 \%}$ at $\mathrm{pH}=12$ as a function of the mass concentration of nanocatalyst; $d$ ) light on-off $\mathrm{H}_{2}$ production evolution under 2.2 bar of argon atmosphere in pure deionized water for a mass concentration of $\mathrm{TiO}_{2} / \mathrm{Cbz}^{2 \%} / \mathrm{Ag}^{3 \%}$ nanocatalyst of $0.62 \mathrm{~g} \cdot \mathrm{L}^{-1}$ at $\mathrm{pH}=7$ (green stars). 


\subsection{Influence of the $\mathrm{pH}$ variation}

The modification of the aqueous phase $\mathrm{pH}$ was first studied with the triptych $\mathrm{TiO}_{2} / \mathrm{Cbz}^{1 \%} / \mathrm{Ag}^{3 \%}$ nanocatalyst (Figure $4 \mathrm{a}$, cyan curves). In acidic environment $(\mathrm{pH}=2$, diluted $\mathrm{H}_{2} \mathrm{SO}_{4}$ aqueous solution), a very weak production of $\mathrm{H}_{2}$ is measured during the first $12 \mathrm{~h}(0.2$ $\left.\mu \mathrm{mol} . \mathrm{g}^{-1} \cdot \mathrm{h}^{-1}\right)$, before an increase of the rate to $1.5 \mu \mathrm{mol} . \mathrm{g}^{-1} \cdot \mathrm{h}^{-1}$ during the next $54 \mathrm{~h}$. On the other hand, if a basic environment is used $(\mathrm{pH}=12, \mathrm{NaOH}$ aqueous solution), the rate remains constant during all the irradiation period $(42 \mathrm{~h})$, and corresponds to the highest measured rate $\left(6.9 \mu \mathrm{mol} . \mathrm{g}^{-1} \cdot \mathrm{h}^{-1}\right.$, Figure 4a).

The photocatalytic activities in basic conditions of the two triptych $\mathrm{TiO}_{2} / \mathrm{Cbz}^{1 \%}$ and $2 \% / \mathrm{Ag}^{3 \%}$ nanocatalysts were then compared. The same tendency is observed with the triptych $\mathrm{TiO}_{2} / \mathrm{Cbz}^{2 \%} / \mathrm{Ag}^{3 \%}$ : the catalytic rate enhancement is superior to 17 times higher in basic conditions $\left(7.0 \mu \mathrm{mol} . \mathrm{g}^{-1} \cdot \mathrm{h}^{-1}\right)$ as compared to neutral conditions $\left(0.4 \mu \mathrm{mol} . \mathrm{g}^{-1} \cdot \mathrm{h}^{-1}\right)$ during the first $20 \mathrm{~h}$ of irradiation, but the rate begins to decrease to $2.3 \mu \mathrm{mol} \cdot \mathrm{g}^{-1} \cdot \mathrm{h}^{-1}$ during the following $60 \mathrm{~h}$.

In acidic medium $(\mathrm{pH}=2)$, the amine group of the anilinyl moieties of $\mathrm{Cbz}$ (Figure 2e) are protonated into the ammonium form [73]. Though this protonated Cbz can be solvated in water and consequently removed from the surface of the triptych nanocatalyst, the two-stage catalytic activity is still observed, with a shorter inducing period, suggesting a faster reorganization of the $\mathrm{Cbz}$ layer in acidic conditions. In these conditions, the reduction potential of water is also modified according to the Nernst equation: $\mathrm{E}_{H^{+} / H_{2}}=E_{H^{+} / H_{2}}^{\circ}-0.06 \mathrm{pH}=-0.12 \mathrm{~V} / \mathrm{NHE}$, which could explain the lower catalytic rate (Figure 4a,b).

In basic conditions $(\mathrm{pH}=12)$, no chemical modification of the $\mathrm{Cbz} \mathrm{NH}_{2}$ groups of the $\mathrm{Cbz}$ can occur, and the $\mathrm{H}_{2}$ production rates are the highest recorded. Moreover, no initial period corresponding to a reorganization of the $\mathrm{Cbz}$ layer happens in this case, while a direct and constant high photocatalytic rate is observed in the first hours of irradiation. The Nernst 
potential of the water reduction is also modified: $\mathrm{E}_{\mathrm{H}_{2} \mathrm{O} / \mathrm{H}_{2}}=E_{\mathrm{H}_{2} \mathrm{O} / \mathrm{H}_{2}}^{\circ}-0.06 \mathrm{pH}=$ $-1.547 \mathrm{~V} / \mathrm{NHE}$ at $\mathrm{pH}=12$ [74], which could explain the high measured catalytic rates for $\mathrm{TiO}_{2} / \mathrm{Cbz}^{1 \%} / \mathrm{Ag}^{3 \%}$ (Figure 4a,b).

\subsection{Influence of the mass-loading of nanocatalysts}

A variation of the mass-loading of $\mathrm{TiO}_{2} / \mathrm{Cbz}^{2 \%} / \mathrm{Ag}^{3 \%}$ nanocatalyst (i.e. the mass concentration in solution) at $\mathrm{pH}=12$ was also tested for the photocatalytic hydrogen production, either by varying the mass of triptych used or by changing the volume of the solution, as follows: $0.62,0.73,0.99$ and 1.68 g.L $\mathrm{L}^{-1}$ (Figure $4 \mathrm{c}$ and Figure S18). Here again, two different catalytic rates are observed, the initial rate being higher than the final rate for the low mass concentrations of nanocatalyst: 0.62 g.L $\mathrm{L}^{-1}$ (from 7.7 to $3.4 \mu \mathrm{mol} . \mathrm{g}^{-1} . \mathrm{h}^{-1}$ ), $0.73 \mathrm{~g} . \mathrm{L}^{-1}$ (from 6.0 to $3.9 \mu \mathrm{mol} . \mathrm{g}^{-1} \cdot \mathrm{h}^{-1}$ ) and $0.99 \mathrm{~g} . \mathrm{L}^{-1}$ (from 7.0 to $2.3 \mu \mathrm{mol} . \mathrm{g}^{-1} \cdot \mathrm{h}^{-1}$ ). In contrast, only the highest nanocatalyst concentration (i.e. 1.68 g. $\mathrm{L}^{-1}$ ) gives a linear hydrogen production rate of 5.1 $\mu \mathrm{mol} . \mathrm{g}^{-1} \cdot \mathrm{h}^{-1}$. It is well-known in the literature that each type of catalyst exhibits its own optimal mass-loading [23, 41].

For comparison, the effect of mass-loading was also checked in pure deionized water $(\mathrm{pH}=$ 7) with the $\mathrm{TiO}_{2} / \mathrm{Cbz}^{2 \%} / \mathrm{Ag}^{3 \%}$ triptych, by decreasing the mass concentration of photocatalyst to $0.62 \mathrm{~g} . \mathrm{L}^{-1}$ instead of $1.0 \mathrm{~g} . \mathrm{L}^{-1}$ in the previous tests (Figure $4 \mathrm{~d}$ ). As expected, the hydrogen production rate was found to increase up to ten times $\left(24.7 \mu \mathrm{mol} \cdot \mathrm{g}^{-1} \cdot \mathrm{h}^{-1}\right.$, Figure $\left.4 \mathrm{~d}\right)$ as compared to the more concentrated sample (Figure $2 \mathrm{~g}$ ). Remarkably, a steady catalytic rate is observed during the first $40 \mathrm{~h}$. After this first period, the irradiation is switched off for the next $30 \mathrm{~h}$ and a decrease of the hydrogen amount in the gas phase is observed (Figure 4d), thus confirming that hydrogen production is really photo-induced. This decrease is explained by the hydrogen measurement process under an over-pressure of argon (2.2 bar) in a constant volume: when a 
small amount of the gas phase of the reactor is injected into the GC for analysis, the amount of $\mathrm{H}_{2}$ decreases within the reactor. This is followed by an injection of pure argon gas to keep the pressure constant at 2.2 bar, thus diluting the $\mathrm{H}_{2}$ amount in the gas phase. When the light is switched on again after this period of darkness, the hydrogen production restarts at a slightly lower rate of $22.1 \mu \mathrm{mol} . \mathrm{g}^{-1} \cdot \mathrm{h}^{-1}$, which is still the highest rate recorded with respect to other catalysts loading. The nanocatalyst proved to be robust after reorganization of the $\mathrm{Cbz}$ layer, with a constant production of $\mathrm{H}_{2}$ during the whole irradiation time.

\subsection{Comparison with published photocatalytic nanomaterials}

The main characteristic and $\mathrm{PC} \mathrm{H}_{2}$ production performances in pure water of the optimized triptych $\mathrm{TiO}_{2} / \mathrm{Cbz}^{2 \%} / \mathrm{Ag}^{3 \%}$ and other photocatalysts described in the recent literature are compared (see Table 1). This comparison is made difficult by the high variability of the experimental parameters used. Indeed, the $\mathrm{H}_{2}$ production was here monitored under a pressure of 2.2 bar, which is representative of practical applications, whereas a major part of published works [59] do not clarify the pressure used within the reactor during the photocatalytic experiments. It is well established that the use of vacuum is more favorable to hydrogen production due to the shift of the chemical equilibrium, but does not correspond to a practical application. Nevertheless, our optimized triptych photocatalyst exhibits a photocatalytic

performance $\left(22.1 \mu \mathrm{mol} . \mathrm{g}^{-1} \cdot \mathrm{h}^{-1}\right)$ and robustness $(90 \mathrm{~h})$ in pure water, i.e. without hole scavengers added and under high pressure ( 2.2 bar), thanks to the dye reorganization occurring onto the nanocatalyst surface. 
Table 1. PC performance of different type of nano-powder photocatalysts used in pure water under UV and/or visible light irradiation; ${ }^{a}$ CDs:

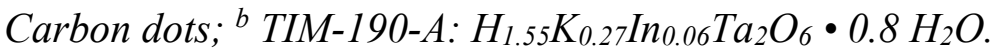

\begin{tabular}{|c|c|c|c|c|c|c|c|c|c|}
\hline Catalyst & Solution & $\begin{array}{l}\text { Specific } \\
\text { Surface } \\
\left(\mathrm{m}^{2} \cdot \mathrm{g}^{-1}\right)\end{array}$ & $\begin{array}{c}\text { Light } \\
\text { intensity }\end{array}$ & $\begin{array}{c}\text { Light } \\
\text { source }\end{array}$ & Irradiation & $\begin{array}{c}\mathbf{H}_{2} \text { production } \\
\text { rate } \\
\left(\mu \mathrm{mol}^{-1} \mathrm{~h}^{-1} \cdot \mathrm{g}^{-1}\right)\end{array}$ & Robustness & Pressure & Reference \\
\hline $\mathrm{ZnIn}_{2} \mathrm{~S}_{4} / \mathrm{Au} / \mathrm{TiO}_{2}$ & Pure water & 63.53 & - & $300 \mathrm{~W}$ Xe & UV-visible & 186.3 & $7 \mathrm{~h}$ & - & [24] \\
\hline $\mathrm{BiVO}_{4} / \mathrm{CDs} / \mathrm{CdS}^{a}$ & $\begin{array}{l}\text { Ultrapure } \\
\text { water }\end{array}$ & - & - & $300 \mathrm{~W}$ Xe & Visible & 15.5 & $25 \mathrm{~h}$ & - & [75] \\
\hline $\begin{array}{c}\text { Quantum sized } \\
\mathrm{BiVO}_{4}\end{array}$ & Pure water & - & - & $500 \mathrm{~W} \mathrm{Xe}$ & UV-visible & 13.3 & $25 \mathrm{~h}$ & - & [76] \\
\hline $\mathrm{Au} / \mathrm{Pt}$ & Pure water & - & - & $250 \mathrm{~W} \mathrm{Hg}$ & UV & 5.7 & $32 \mathrm{~h}$ & - & [77] \\
\hline TIM-190-A ${ }^{b}$ & Pure water & - & $33 \mathrm{~mW} \cdot \mathrm{cm}^{-2}$ & $500 \mathrm{~W} \mathrm{Hg}$ & UV & 6.0 & $8 \mathrm{~h}$ & - & [78] \\
\hline $\mathrm{TiO}_{2} / \mathrm{ZnTe} / \mathrm{Au}$ & Pure water & - & $96 \mathrm{~mW} \cdot \mathrm{cm}^{-2}$ & $300 \mathrm{~W}$ Xe & UV-visible & 3344.0 & $72 \mathrm{~h}$ & - & [79] \\
\hline $\mathrm{TiO}_{2} / \mathrm{Cbz}^{2 \%} / \mathrm{Ag}^{3 \%}$ & Pure water & 37.07 & $200 \mathrm{~mW} \cdot \mathrm{cm}^{-2}$ & $300 \mathrm{~W} \mathrm{Xe}$ & UV-visible & 22.1 & $90 \mathrm{~h}$ & $2.2 \mathrm{bar}$ & This study \\
\hline
\end{tabular}


A possible mechanism of photocatalysis is here proposed: the reorganized organic layer absorbs visible light and the resulting excited state (i.e. the combination of the two transitions HOMO1/HOMO $\rightarrow$ LUMO/LUMO+1 of the Cbz molecules, as previously reported [54-57]) could relax by transferring the excited electrons to the $\mathrm{CB}$ of the $\mathrm{Ag} \mathrm{NPs}_{\text {or }} \mathrm{TiO}_{2} \mathrm{SC}$ (Figure 5). The Ag NPs, thanks to their surface plasmon resonance properties (corresponding to the interband $4 \mathrm{~d} / 5 \mathrm{~s}$ transition), may then transfer electrons to $\mathrm{TiO}_{2}$ via a plasmon-induced electronic transfer process at the Schottky junction between the $\mathrm{Ag}$ and $\mathrm{TiO}_{2} \mathrm{NP}$. Finally, the multiple heterojunctions between the organic layer, metallic $\mathrm{Ag} \mathrm{NP}$ and/or $\mathrm{SC} \mathrm{TiO}_{2} \mathrm{NP}$ lead to a particularly robust triptych nanocatalyst.

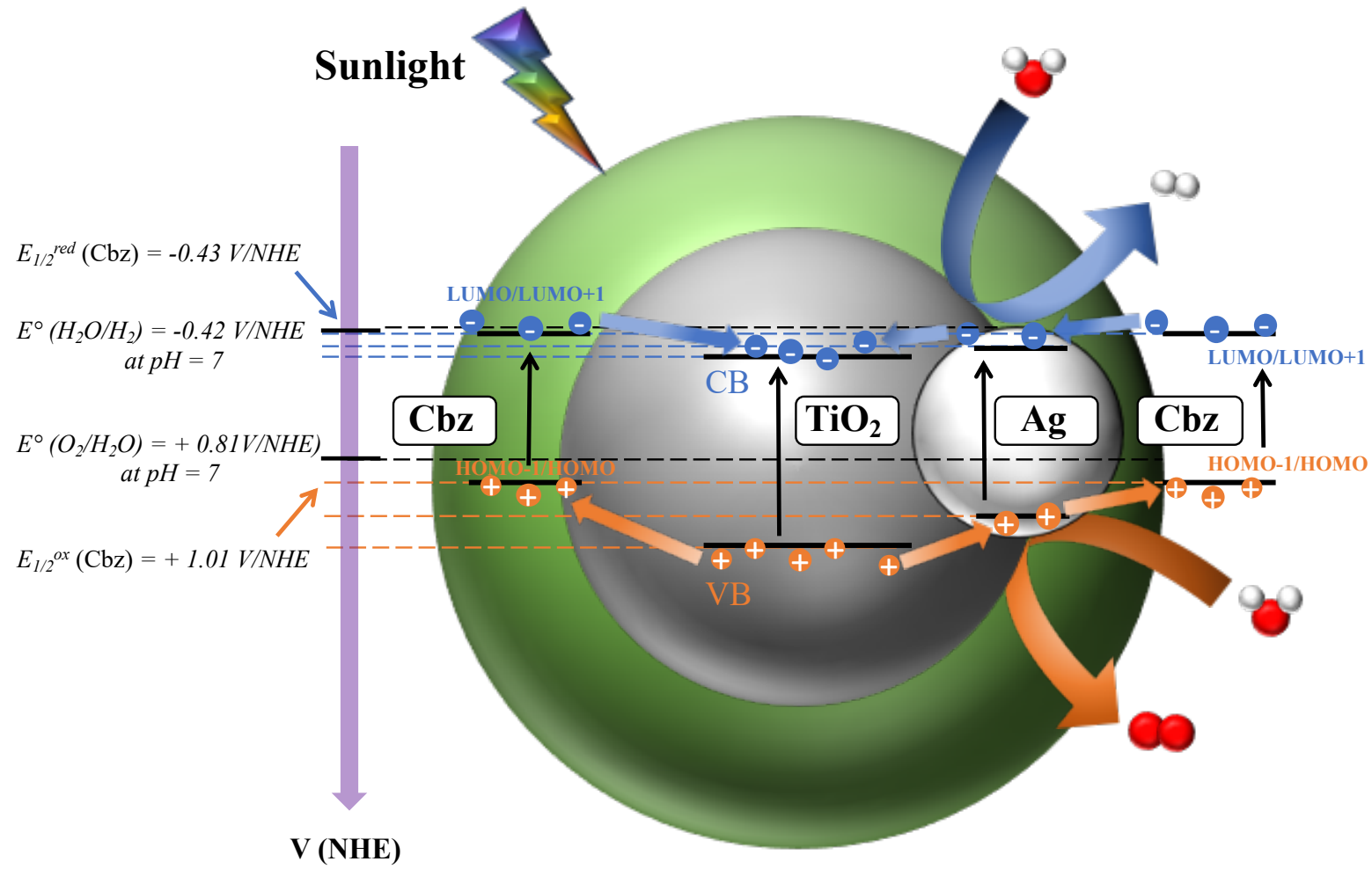

Figure 5. Representation of a possible mechanism for the photo-induced electron transfer in $\mathrm{TiO}_{2} / \mathrm{Cbz}^{2 \%} / \mathrm{Ag}^{3 \%}$ nanocatalyst. The semiconducting $\mathrm{TiO}_{2}$ and plasmonic $\mathrm{Ag}$ NPs are depicted in grey and white, respectively, whereas the Cbz layer is depicted in green. For each of these 
three components, the band diagram is also depicted. $V B=$ valence band, $C B=$ conductive band.

\section{Conclusion}

In summary, the relevance of novel triptych nanocatalysts for the photocatalytic production of hydrogen from pure deionized water involving a nanomaterial made of a $\mathrm{TiO}_{2}$ semiconducting substrate and plasmonic Ag nanoparticles surrounded by a monolayer of photosensitive carbo-benzene (Cbz) macrocyclic molecules is established. The interest of using a carbo-benzene to form an efficient conductive and photosensitive layer in a triptych nanocatalyst for green hydrogen production applications was demonstrated from pure deionized water. The $\mathrm{TiO}_{2} / \mathrm{Cbz}^{2 \%} / \mathrm{Ag}^{3 \%}$ triptych has been shown to undergo a reorganization of the photosensitive layer onto the nanomaterial surface during photocatalysis, leading to an enhancement of the hydrogen production rate with a factor superior to five $\left(2.2 \mu \mathrm{mol} . \mathrm{g}^{-1} \cdot \mathrm{h}^{-1}\right)$ after an induction period of lower efficiency. It was shown that a thin monolayer $(2 \mathrm{~nm})$ of carbo-benzene surrounding the $\mathrm{TiO}_{2} / \mathrm{Ag}$ nanomaterial is required. The amounts of semiconductor, plasmonic NPs and photosensitizer were finely optimized, too low or too high amounts of each component dramatically decreasing the photocatalytic efficiency. The $\mathrm{pH}$ of the aqueous solution was also shown to have a dramatic effect on both the reorganization of the Cbz layer and the hydrogen production rate. The mass-loading of nanocatalyst was finally shown to be of crucial importance, a lower mass concentration in the reactor leading to a ten times increase of the catalysis rate, reaching $22.1 \mu \mathrm{mol} . \mathrm{g}^{-1} \cdot \mathrm{h}^{-1}$ in neutral conditions.

This work demonstrates that a fine tuning of the amount of photo-sensitizer is required to enhance the photocatalytic activity, particularly in the hydrogen production field. The robustness of the optimized $\mathrm{TiO}_{2} / \mathrm{Cbz}^{2 \%} / \mathrm{Ag}^{3 \%}$ triptych nanocatalyst, still active after $90 \mathrm{~h}$ of 
reaction, is a remarkable outcome, especially under applicative conditions, i.e. pure deionized water without any hole scavenger added, at ambient temperature and under argon pressure (2.2 bar). Further optimizations of the operating conditions (catalyst concentration, nature of the aqueous medium, hole scavenger additives, temperature...) are currently underway to increase the yield of $\mathrm{H}_{2}$ production.

\section{Associated content}

Full experimental and characterization details. This material is available free of charges via the Internet at: https://doi.org/10.

\section{Author Information}

\section{Corresponding author}

Correspondence to:

Kévin Cocq, kevin.cocq@gmail.com

Jérémy Cure, jgc170130@utdallas.edu

Gérald Casterou, gerald.casterou@gmail.com

\section{Author contributions}

K. C., J. C. and G. C. initiated the triptych material preparation. K.C. and J.C. prepared the manuscript and supervised the project. H. A. prepared the synthesis of the tryptich photocatalysts and performed all the $\mathrm{H}_{2}$ production measurements. $\mathrm{KC}$ prepared the photosensitive carbo-benzene molecule, the silver amidinate complexe and performed with H.A. the $\mathrm{H}_{2}$ production measurements. J.C. performed XPS, Infrared and Raman experiments. K. C. L. performed the BET measurements. All STEM-HAADF and TEM images were 
obtained by V. C.. L. V. performed the XRD measurements. P. F., K. F. and M. L. K. supervised the project, the preparation of silver decorated metal oxide and contributed to the manuscript preparation. V. M. and R. C. supervised the project, provided support for the synthesis of carbobenzene molecules and contributed for the manuscript preparation. Y. J. C. provided support for the XPS, Infrared and Raman experiments.

\section{Competting financial interests}

The authors declare no competting financial interests.

\section{Acknowledgement}

All the synthesis and spectroscopic characterization were supported by Centre National de la Recherche Scientifique CNRS (PhotoH2 prematuration project). The GC measurements were supported by Université de Toulouse (IDEX MUSE project). Jean-François Veyan is acknowledged for his help in the measurements of the XPS spectra.

\section{References}

[1] S. Dutta, A review on production, storage of hydrogen and its utilization as an energy resource, Journal of Industrial and Engineering Chemistry, 20 (2014) 1148-1156.

[2] ADEME, Technical Review: The Role of Hydrogen in the Energy Transition, (2018) https://www.ademe.fr/the-role-of-hydrogen-in-the-energy-transition-technical-review, accessed 2019/12/22.

[3] M. Maghami, R. Hassani, C. Gomes, H. Hizam, M. Othman, M. Behmanesh, Hybrid energy management with respect to a hydrogen energy system and demand response, International Journal of Hydrogen Energy, 45 (2020) 1499-1509.

[4] A. Fujishima, K. Honda, Electrochemical Photolysis of Water at a Semiconductor Electrode, Nature, 238 (1972) 37-38.

[5] G. Liu, C. Sun, H. Yang, S. Smith, L. Wang, G. Lu, H. Cheng, Nanosized anatase $\mathrm{TiO}_{2}$ single crystals for enhanced photocatalytic activity, Chemical Communications, 46 (2010) 755-757.

[6] J.-S. Yang, W.-P. Liao, J.-J. Wu, Morphology and Interfacial Energetics Controls for Hierarchical Anatase/Rutile $\mathrm{TiO}_{2}$ Nanostructured Array for Efficient Photoelectrochemical Water Splitting, ACS Applied Material \& Interfaces, 5 (2013) 7425-7431. 
[7] D. Chen, R. Caruso, Recent Progress in the Synthesis of Spherical Titania Nanostructures and Their Applications, Advanced Functional Materials, 23 (2013) 1356-1374.

[8] S. Hwang, J. Yun, J. Jang, Multi-Shell Porous $\mathrm{TiO}_{2}$ Hollow Nanoparticles for Enhanced Light Harvesting in Dye-sensitized Solar Cells, Advanced Functional Materials, 24 (2014) 7619-7626.

[9] Y. Pu, G. Wang, K. Chang, Y. Ling, Y. Lin, B. Fitzmorris, C. Liu, X. Lu, Y. Tong, J. Zhang, Y. Hsu, Y. Li, Au Nanostructure-Decorated $\mathrm{TiO}_{2}$ Nanowires Exhibiting Photoactivity Across Entire UV-visible Region for Photoelectrochemical Water Splitting, Nano Letters, 13 (2013) 3817-3823.

[10] Z. Zhang, L. Zhang, M. Hedhili, H. Zhang, P. Wang, Plasmonic Gold Nanocrystals Coupled with Photonic Crystal Seamlessly on $\mathrm{TiO}_{2}$ Nanotube Photoelectrodes for Efficient Visible Light Photoelectrochemical Water Splitting, Nano Letters, 13 (2013) 14-20.

[11] H. Gao, P. Zhang, J. Zhao, Y. Zhang, J. Hu, G. Shao, Plasmon enhancement on photocatalytic hydrogen production over the Z-scheme photosynthetic heterojunction system, Applied Catalysis B-Environmental, 210 (2017) 297-305.

[12] J. Cure, E. Mattson, K. Cocq, H. Assi, S. Jensen, K. Tan, M. Catalano, S. Yuan, H. Wang, L. Feng, P. Zhang, S. Kwon, J.-F. Veyan, Y. Cabrera, G. Zhang, J. Li, M. Kim, H. Zhou, Y. J. Chabal, T. Thonhauser, High stability of ultra-small and isolated gold nanoparticles in metal-organic framework materials, Journal of Materials Chemistry A, 7 (2019) 17536-17546.

[13] X. Xing, S. Tang, H. Hong, H. Jin, Concentrated solar photocatalysis for hydrogen generation from water by titania-containing gold nanoparticles, International Journal of Hydrogen Energy, 45 (2020) 9612-9623.

[14] B. Han, L. Wu, J. Li, X. Wang, Q. Peng, N. Wang, X. Li, A nanoreactor based on $\mathrm{SrTiO}_{3}$ coupled $\mathrm{TiO}_{2}$ nanotubes confined Au nanoparticles for photocatalytic hydrogen evolution, International Journal of Hydrogen Energy, 45 (2020) 1559-1568.

[15] M. Ge, C. Cao, S. Li, Y. Tang, L. Wang, N. Qi, J. Huang, K. Zhang, S. Al-Deyab, Y. Lai, In situ plasmonic Ag nanoparticle anchored $\mathrm{TiO}_{2}$ nanotube arrays as visible-light-driven photocatalysts for enhanced water splitting, Nanoscale, 8 (2016) 5226-5234.

[16] A. Sreedhar, T. V. M. Sreekanth, J. H. Kwon, J. Yi, Y. Sohn, J. S. Gwag, Ag nanoparticles decorated ion-beam-assisted $\mathrm{TiO}_{2}$ thin films for tuning the water splitting activity from UV to visible light harvesting, Ceramics International, 43 (2017) 12814-12821.

[17] C.-F. Liu, T.-P. Perng, Fabrication and band structure of $\mathrm{Ag}_{3} \mathrm{PO}_{4}-\mathrm{TiO}_{2}$ heterojunction with enhanced photocatalytic hydrogen evolution, International Journal of Hydrogen Energy, 45 (2020) 149-159.

[18] J. Liu, G. Liu, M. Li, W. Shen, Z. Liu, J. Wang, J. Zhao, L. Jiang, Y. Song, Enhancement of photochemical hydrogen evolution over Pt-loaded hierarchical titania photonic crystal, Energy \& Environmental Science, 3 (2010) 1503-1506.

[19] J. Yu, L. Qi, M. Jaroniec, Hydrogen Production by Photocatalytic Water Splitting over $\mathrm{Pt} / \mathrm{TiO}_{2}$ Nanosheets with Exposed (001) Facets, Journal of Physical Chemistry C, 114 (2010) 13118-13125.

[20] S. Bai, L. Yang, C. Wang, Y. Lin, J. Lu, J. Jiang, Y. Xiong, Boosting Photocatalytic Water Splitting: Interfacial Charge Polarization in Atomically Controlled Core-Shell Cocatalysts, Angewandte Chemie-International Edition, 54 (2015) 14810-14814.

[21] Y. Liu, S. Yang, S. Zhang, H. Wang, H. Yu, Y. Cao, F. Peng, Design of cocatalyst loading position for photocatalytic water splitting into hydrogen in electrolyte solutions, International Journal of Hydrogen Energy, 43 (2018) 5551-5560.

[22] U. Caudillo-Flores, A. Kubacka, T. Berestok, T. Zhang, J. Llorca, J. Arbiol, A. Cabot, M. Fernandez-Garcia, Hydrogen photogeneration using ternary $\mathrm{CuGaS}_{2}-\mathrm{TiO}_{2}-\mathrm{Pt}$ nanocomposites, International Journal of Hydrogen Energy, 45 (2020) 1510-1520. 
[23] P. Ravi, V. N. Rao, M. V. Shankar, M. Sathish, CuO@NiO core-shell nanoparticles decorated anatase $\mathrm{TiO}_{2}$ nanospheres for enhanced photocatalytic hydrogen production, International Journal of Hydrogen Energy, 45 (2020) 7517-7529.

[24] G. Yang, H. Ding, D. Chen, J. Feng, Q. Hao, Y. Zhu, Construction of urchin-like $\mathrm{ZnIn}_{2} \mathrm{~S}_{4}-\mathrm{Au}-\mathrm{TiO}_{2}$ heterostructure with enhanced activity for photocatalytic hydrogen evolution, Applied Catalysis B-Environmental, 234 (2018) 260-267.

[25] N. Subha, M. Mahalakshmi, S. Monika, B. Neppolian, $\mathrm{Ni}(\mathrm{OH})_{2}-\mathrm{Cu}_{\mathrm{x}} \mathrm{O}-\mathrm{TiO}_{2}$

nanocomposite for the enhanced $\mathrm{H}_{2}$ production under solar light: The mechanistic pathway, International Journal of Hydrogen Energy, 45 (2020) 7552-7561.

[26] W. Youngblood, S. Lee, K. Maeda, T. Mallouk, Visible Light Water Splitting Using Dye-Sensitized Oxide Semiconductors, Accounts of Chemical Research, 42 (2009) 19661973.

[27] E. Reisner, D. J. Powell, C. Cavazza, J. C. Fontecilla-Camps, F. A. Armstrong, Visible Light-Driven $\mathrm{H}_{2}$ Production by Hydrogenases Attached to Dye-Sensitized $\mathrm{TiO}_{2}$ Nanoparticles, Journal of American Chemical Society, 131 (2009) 18457-18466. [28] X. Zhang, Y. Sun, X. Cui, Z. Jiang, A green and facile synthesis of $\mathrm{TiO}_{2} /$ graphene nanocomposites and their photocatalytic activity for hydrogen evolution, International Journal of Hydrogen Energy, 37 (2012) 811-815.

[29] S. Gonuguntla, A. Tiwari, S. Madanaboina, G. Lingamallu, U. Pal, Revealing high hydrogen evolution activity in zinc porphyrin sensitized hierarchical porous $\mathrm{TiO}_{2}$ photocatalysts, International Journal of Hydrogen Energy, 45 (2020) 7508-7516. [30] D. Chaudhary, S. Singh, V. Vankar, N. Khare, A ternary Ag/ $/ \mathrm{TiO}_{2} / \mathrm{CNT}$ photoanode for efficient photoelectrochemical water splitting under visible light irradiation, International Journal of Hydrogen Energy, 42 (2017) 7826-7835.

[31] M. Wang, J. Han, H. Xiong, R. Guo, Yolk@Shell Nanoarchitecture of Au@r-GO/TiO Hybrids as Powerful Visible Light Photocatalysts, Langmuir, 31 (2015) 6220-6228.

[32] R. Boppella, S. Kochuveedu, H. Kim, M. Jeong, F. Mota, J. Park, D. Kim, PlasmonSensitized Graphene/ $\mathrm{TiO}_{2}$ Inverse Opal Nanostructures with Enhanced Charge Collection Efficiency for Water Splitting, ACS Applied Materials and Interfaces, 9 (2017) 7075-7083. [33] Y. Yang, E. Liu, H. Dai, L. Kang, H. Wu, J. Fan, X. Hu, H. Liu, Photocatalytic activity of $\mathrm{Ag}-\mathrm{TiO}_{2}$-graphene ternary nanocomposites and application in hydrogen evolution by water splitting, International Journal of Hydrogen Energy, 39 (2014) 7664-7671.

[34] F. Sheu, C. Cho, Investigation of the appropriate content of graphene in $\mathrm{Ag}-\mathrm{TiO}_{2}-$ graphene ternary nanocomposites applied as photocatalysts, International Journal of Hydrogen Energy, 42 (2017) 17020-17029.

[35] Z. Wang, Z. Low, X. Zeng, B. Su, Y. Yin, C. Sun, T. Williams, H. Wang, X. Zhang, Vertically-heterostructured $\mathrm{TiO}_{2}$-Ag-rGO ternary nanocomposite constructed with $\{001\}$ facetted $\mathrm{TiO}_{2}$ nanosheets for enhanced Pt-free hydrogen production, International Journal of Hydrogen Energy, 43 (2018) 1508-1515.

[36] X. Guo, X. Li, L. Qin, S. Kang, G. Li, A highly active nano-micro hybrid derived from $\mathrm{Cu}$-bridged $\mathrm{TiO}_{2}$ /porphyrin for enhanced photocatalytic hydrogen production, Applied Catalysis B-Environmental, 243 (2019) 1-9.

[37] R.A. Rather, S. Singh, B. Pal, A g-C ${ }_{3} \mathrm{~N}_{4}$ surface passivated highly photoactive $\mathrm{Au}-\mathrm{TiO}_{2}$ tubular nanostructure for the efficient $\mathrm{H}_{2}$ production from water under sunlight irradiation, Applied Catalysis B : Environmental, 213 (2017) 9-17.

[38] Y. Zou, J.-W. Shi, D. Ma, Z. Fan, C. Niu, L. Wang, Fabrication of g- $\mathrm{C}_{3} \mathrm{~N}_{4} / \mathrm{Au} / \mathrm{C}-\mathrm{TiO}_{2}$ Hollow Structures as Visible-Light-Driven Z-Scheme Photocatalysts with Enhanced Photocatalytic $\mathrm{H}_{2}$ Evolution, ChemCatChem, 9 (2017) 3752-3761.

[39] C. Marchal, T. Cottineau, M. G. Mendez-Medrano, C. Colbeau-Justin, V. Caps, V. Keller, $\mathrm{Au} / \mathrm{TiO}_{2}-\mathrm{g}-\mathrm{C}_{3} \mathrm{~N}_{4}$ Nanocomposites for Enhanced Photocatalytic $\mathrm{H}_{2}$ Production from Water 
under Visible Light Irradiation with Very Low Quantities of Sacrificial Agents, Advanced Energy Materials, 8 (2018) 1702142.

[40] J. Kuang, Z. Xing, J. Yin, Z. Li, Q. Zhu, W. Zhou, Surface plasma Ag-decorated singlecrystalline $\mathrm{TiO}_{2-\mathrm{x}}(\mathrm{B})$ nanorod/defect-rich $\mathrm{g}-\mathrm{C}_{3} \mathrm{~N}_{4}$ nanosheet ternary superstructure $3 \mathrm{D}$ heterojunctions as enhanced visible-light-driven photocatalyst, Journal of Colloid and Interface Science, 542 (2019) 63-72.

[41] N. Fajrina, M. Tahir, Engineering approach in stimulating photocatalytic $\mathrm{H}_{2}$ production in a slurry and monolithic photoreactor systems using Ag-bridged Z-scheme $\mathrm{pCN} / \mathrm{TiO}_{2}$ nanocomposite, Chemical Engineering Journal, 374 (2019) 1076-1095.

[42] J. Wang, J. Huang, H. Xie, A. Qu, Synthesis of g- $\mathrm{C}_{3} \mathrm{~N}_{4} / \mathrm{TiO}_{2}$ with enhanced photocatalytic activity for $\mathrm{H}_{2}$ evolution by a simple method, International Journal of Hydrogen Energy, 39 (2014) 6354-6363.

[43] J. Cure, K. Cocq, A. Mlayah, T. Hungria, P. Alphonse, Y. J. Chabal, V. Maraval, R. Chauvin, A. Esteve, C. Rossi, A Triptych Photocatalyst Based on the Co-Integration of Ag Nanoparticles and Carbo-Benzene Dye into $\mathrm{a} \mathrm{TiO}_{2}$ Thin Film, International Journal of Hydrogen Energy, 44 (2019) 26347-26360.

[44] Y. Goto, T. Hisatomi, Q. Wang, T. Higashi, K. Ishikiriyama, T. Maeda, Y. Sakata, S. Okunaka, H. Tokudome, M. Katayama, S. Akiyama, H. Nishiyama, Y. Inoue, T. Takewaki, T. Setoyama, T. Minegishi, T. Takata, T. Yamada, K. Domen, A Particulate Photocatalyst Water-Splitting Panel for Large-Scale Solar Hydrogen Generation, Joule, 2 (2018) 509-520. [45] T. Takata, K. Domen, Particulate Photocatalysts for Water Splitting: Recent Advances and Future Prospects, ACS Energy Letters, 4 (2019) 542-549.

[46] K. Cocq, C. Lepetit, V. Maraval, R. Chauvin, "Carbo-aromaticity" and novel carboaromatic compounds, Chemical Society Reviews, 44 (2015) 6535-6559.

[47] Z. Li, M. Smeu, A. Rives, V. Maraval, R. Chauvin, M. Ratner, E. Borguet, Towards graphyne molecular electronics, Nature Communications, 6 (2015).

[48] J. Cure, Y. Coppel, T. Dammak, P. Fazzini, A. Mlayah, B. Chaudret, P. Fau, Monitoring the Coordination of Amine Ligands on Silver Nanoparticles Using NMR and SERS, Langmuir, 31 (2015) 1362-1367.

[49] B. S. Lim, A. Rahtu, J.-S. Park, R. G. Gordon, Synthesis and Characterization of Volatile, Thermally Stable, Reactive Transition Metal Amidinates, Inorganic Chemistry, 42 (2003) 7951-7958.

[50] K. Cocq, C. Barthes, A. Rives, V. Maraval, R. Chauvin, Synthesis of Functional Carbobenzenes with Functional Properties: The $C_{2}$ Tether Key, Synlett, 30 (2019) 30-43.

[51] T. de Freitas Paulo, V. Bernardes-Génisson, V. Maraval, R. Chauvin, manuscript in preparation, (2020).

[52] A. A. Melvin, K. Illath, T. Das, T. Raja, S. Bhattacharyya, C. S. Gopinath, M-Au/TiO

$(\mathrm{M}=\mathrm{Ag}, \mathrm{Pd}$, and $\mathrm{Pt})$ nanophotocatalyst for overall solar water splitting: role of interfaces, Nanoscale, 7 (2015) 13477-13488.

[53] Z. W. Seh, S. Liu, M. Low, S.-Y. Zhang, Z. Liu, A. Mlayah, M.-Y. Han, Janus Au-TiO Photocatalysts with Strong Localization of Plasmonic Near-Fields for Efficient Visible-Light Hydrogen Generation, Advanced Materials, 24 (2012) 2310-2314.

[54] I. Baglai, M. de Anda-Villa, R. Barba-Barba, C. Poidevin, G. Ramos-Ortiz, V. Maraval, C. Lepetit, N. Saffon-Merceron, J. Maldonado, R. Chauvin, Difluorenyl carbo-Benzenes: Synthesis, Electronic Structure, and Two-Photon Absorption Properties of Hydrocarbon Quadrupolar Chromophores, Chemistry-a European Journal, 21 (2015) 14186-14195.

[55] D. Listunov, C. Duhayon, A. Poater, S. Mazères, A. Saquet, V. Maraval, R. Chauvin, Steric/n-electronic insulation of the carbo-benzene ring: dramatic effect of tert-butyl vs phenyl crowns on geometric, chromophoric, redox and magnetic properties, Chemistry-a European Journal, 24 (2018) 10699-10710. 
[56] L. Leroyer, C. Lepetit, A. Rives, V. Maraval, N. Saffon-Merceron, D. Kandaskalov, D. Kieffer, R. Chauvin, From Hexaoxy-[6]Pericyclynes to Carbo-Cyclohexadienes, CarboBenzenes, and Dihydro-Carbo-Benzenes: Synthesis, Structure, and Chromophoric and Redox Properties, Chemistry-a European Journal, 18 (2012) 3226-3240.

[57] C. Zhu, A. Poater, C. Duhayon, B. Kauffmann, A. Saquet, V. Maraval, R. Chauvin, Carbo-biphenyls and Carbo-terphenyls: Oligo(phenylene ethynylene) Ring Carbo-mers, Angewandte Chemie-International Edition, 57 (2018) 5640-5644.

[58] A. Sreedhar, T. Sreekanth, J. Kwon, J. Yi, Y. Sohn, J. Gwag, Ag nanoparticles decorated ion-beam-assisted $\mathrm{TiO}_{2}$ thin films for tuning the water splitting activity from UV to visible light harvesting, Ceramics International, 43 (2017) 12814-12821.

[59] Z. Wang, C. Li, K. Domen, recent developments in heterogeneous photocatalysts for solar-driven overall water-splitting, Chemical Society Reviews, 48 (2018) 2019-2125.

[60] C. Zhu, T. Wang, C. Su, S. Lee, A. Rives, C. Duhayon, B. Kauffmann, V. Maraval, C. Chen, H. Hsu, R. Chauvin, 3D and 2D supramolecular assemblies and thermotropic behaviour of a carbo-benzenic mesogen, Chemical Communications, 53 (2017) 5902-5905.

[61] X. Chen, L. Jensen, Understanding the shape effect on the plasmonic response of small ligand coated nanoparticles, Journal of Optics, 18 (2016) 074009/074001 - 074009/074009.

[62] C. Barriere, K. Piettre, V. Latour, O. Margeat, C.-O. Turrin, B. Chaudret, P. Fau, Ligand effects on the air stability of copper nanoparticles obtained from organometallic synthesis, Journal of Materials Chemistry A, 22 (2012) 2279-2285.

[63] B. N. J. Persson, On the theory of surface-enhanced Raman scattering, Chemical Physics Letters, 82 (1981) 561-565.

[64] I. Romero, A. J., W. Bryant Garnett, F. J. Garcia de Abajo, Plasmons in nearly touching metallic nanoparticles: singular response in the limit of touching dimers, Optics Express, 14 (2006) 9988-9999.

[65] C. Das, B. Ananthoju, A. K. Dhara, M. Aslam, S.K. Sarkar, K. R. Balasubramaniam, Electron-selective $\mathrm{TiO}_{2} / \mathrm{CVD}$-Graphene Layers for Photocorrosion Inhibition in $\mathrm{Cu}_{2} \mathrm{O}$ Photocathodes, Advanced Materials \& Interfaces, 4 (2017) 1700271.

[66] Y. Tang, X. Hu, C. Liu, Perfect Inhibition of CdS photocorrosion by graphene sheltering engineering on $\mathrm{TiO}_{2}$ nanotube array for highly stable photocatalytic activity, Physical Chemistry Chemical Physics, 16 (2014) 25321-25329.

[67] Z. Yang, P. Zhang, Y. Ding, Y. Jiang, Z. Long, W. Dai, Facile synthesis of Ag/ZnO heterostructures assisted by UV irradiation: Highly photocatalytic property and enhanced photostability, Materials Research Bulletin, 46 (2011) 1625-1631.

[68] K. Manesh, A. Gopalan, K. Lee, S. Komathi, Silver nanoparticles distributed into polyaniline bridged silica network: A functional nanocatalyst having synergistic influence for catalysis, Catalysis Communications, 11 (2010) 913-918.

[69] A. Panacek, R. Prucek, J. Hrbac, T. Nevecna, J. Steffkova, R. Zboril, L. Kvitek, Polyacrylate-Assisted Size Control of Silver Nanoparticles and Their Catalytic Activity, Chemistry of Materials, 26 (2014) 1332-1339.

[70] M. Raza, Z. Kanwal, A. Rauf, A. Sabri, S. Riaz, S. Naseem, Size- and Shape-Dependent Antibacterial Studies of Silver Nanoparticles Synthesized by Wet Chemical Routes, Nanomaterials, 6 (2016).

[71] J. Helmlinger, C. Sengstock, C. Gross-Heitfeld, C. Mayer, T. Schildhauer, M. Koller, M. Epple, Silver nanoparticles with different size and shape: equal cytotoxicity, but different antibacterial effects, RSC Advances, 6 (2016) 18490-18501.

[72] S. Ganaie, R. Rajalakshmi, T. Abbasi, S. Abbasi, Clean green synthesis of silver nanoparticles with shape/size control using aquatic weed Pistia stratiotes and their antioxidant, antibacterial and catalytic activity, Journal of the Indian Chemical Society, 94 (2017) 1203-1212. 
[73] $\mathrm{pKa}$ of $\mathrm{R}-\mathrm{NH}_{3}{ }^{+} / \mathrm{R}-\mathrm{NH}_{2}=4.6$ with $\mathrm{R}=\mathrm{Ph}$.

[74] It is evident that, in basic conditions, the reduction of water occurs with $\mathrm{H}_{2} \mathrm{O} / \mathrm{HO}^{-}$couple (with $\mathrm{E}^{\circ}=-0.827 \mathrm{~V} / \mathrm{ESH}$ ) and the reaction is $\mathrm{H}_{2} \mathrm{O}+2 \mathrm{e}^{-}=\mathrm{H}_{2}+2 \mathrm{HO}^{-}$. As a reminder, $\left[\mathrm{H}^{+}\right]=$ $10^{-12}$ mol. $\mathrm{L}^{-1}$ and $\left[\mathrm{HO}^{-}\right]=10^{-2} \mathrm{~mol} . \mathrm{L}^{-1}$ at $\mathrm{pH}=12$.

[75] X. Wu, J. Zhao, L. Wang, M. Han, M. Zhang, H. Wang, H. Huang, Y. Liu, Z. Kang, Carbon dots as solid-state electron mediator for $\mathrm{BiVO}_{4} / \mathrm{CDs} / \mathrm{CdS} \mathrm{Z}$-scheme photocatalyst working under visible light, Applied Catalysis B-Environmental, 206 (2017) 501-509.

[76] S. Sun, W. Wang, D. Li, L. Zhang, D. Jiang, Solar Light Driven Pure Water Splitting on Quantum Sized BiVO 4 without any Cocatalyst, ACS Catalysis, 4 (2014) 3498-3503.

[77] B. Tian, Q. Lei, B. Tian, W. Zhang, Y. Cui, Y. Tian, UV-driven overall water splitting using unsupported gold nanoparticles as photocatalysts, Chemical Communication, 54 (2018) 1845-1848.

[78] M. Hsieh, G. Wu, W. Liu, W. Goddard, C. Yang, Nanocomposites of Tantalum-Based Pyrochlore and Indium Hydroxide Showing High and Stable Photocatalytic Activities for Overall Water Splitting and Carbon Dioxide Reduction, Angewandte Chemie-International Edition, 53 (2014) 14216-14220.

[79] W. Zhang, Y. Hu, C. Yan, D. Hong, R. Chen, X. Xue, S. Yang, Y. Tian, Z. Tie, Z. Jin, Surface plasmon resonance enhanced direct Z-scheme $\mathrm{TiO}_{2} / \mathrm{ZnTe} / \mathrm{Au}$ nanocorncob heterojunctions for efficient photocatalytic overall water splitting, Nanoscale, 11 (2019) 90539060 . 